\title{
Recent Advances in Molecular Toxicology of Cadmium and Nickel.
}

Ewa Kurowska ${ }^{1}$ and Wojciech Bal ${ }^{1,2}$

${ }^{1}$ Institute of Biochemistry and Biophysics,

Polish Academy of Sciences,

Pawińskiego 5a, 02-106 Warsaw, Poland;

${ }^{2}$ Central Institute for Labour Protection - National Research Institute,

Czerniakowska 16, 00-701 Warsaw, Poland.

Contact information: Wojciech Bal, wbal@ibb.waw.pl, phone: +48-22-592-2346, fax: +48$22-658-4636$ 


\begin{abstract}
Cadmium (Cd) and nickel (Ni) are two toxic elements which are widespread in the human environment, but less recognized as hazardous by the general public. Herein, we describe molecular mechanisms of their toxicity towards humans, in the context of general chemical and toxicological properties of these metals. Following the introductory remarks, the routes of exposure are outlined. The next chapter covers the health hazards posed by cadmium and nickel with the main stress placed on diseases like cadmium induced nephropathy, reproductive disorders due to cadmium exposure, cadmium related COPD and cadmium carcinogenesis. In respect to nickel, acute toxicity, nickel allergy and nickel carcinogenicity were described. This overall description provides the basis for a detailed account of molecular mechanisms of cadmium and nickel toxicity. They include the involvement of metallothioneins and their role in the transport of $\mathrm{Cd}(\mathrm{II})$ ions, and the role of oxidative damage and DNA repair inhibition in cadmium carcinogenesis. The final issue covered in respect to molecular mechanisms of cadmium toxicity is its influence on cellular junctions. Molecular mechanisms of nickel toxicity are divided into subjects of nickel allergy and several mechanisms related to its carcinogenicity. The discussion is completed by the presentation of nickel and cadmium interactions with zinc fingers as a possible common ground of their molecular toxicity.
\end{abstract}




\section{Contents:}

1. Introduction

2. Chemical properties and routes of exposure to cadmium and nickel compounds

2.1. Chemical properties of cadmium

2.2. Chemical properties of nickel

2.3. Exposure to cadmium

2.4. Exposure to nickel

3. Health hazards due to exposures to cadmium and nickel compounds

3.1. Health hazards related to cadmium exposure

3.1.1. Cadmium nephropathy

3.1.2. Reproductive disorders due to cadmium exposure

3.1.3. Cadmium and COPD

3.1.4. Cadmium carcinogenesis

3.2. Health hazards related to nickel exposure

3.2.1. Acute nickel toxicity

3.2.2. Nickel allergy

3.2.3. Nickel carcinogenesis

4. Molecular mechanisms of cadmium and nickel toxicity

4.1. Molecular mechanisms of cadmium toxicity

4.1.1. Metallothionein and extracellular transport of $\mathrm{Cd}(\mathrm{II})$ ions

4.1.2. Cadmium carcinogenesis: oxidative damage and DNA repair inhibition

4.1.3. Effects of $\mathrm{Cd}(\mathrm{II})$ on cellular junctions

4.2. Molecular mechanisms in nickel toxicity

4.2.1. Nickel allergy

4.2.2. Molecular mechanisms in nickel carcinogenesis 
4.3. Interactions with zinc fingers - a common target for cadmium and nickel.

5. Summary 


\section{INTRODUCTION}

Factors eliciting toxicity can be subdivided into physical, chemical and biological ones. Physical toxic agents include a wide section of the electromagnetic radiation spectrum, from gamma rays through X-rays and ultraviolet, to infrared and microwaves, corpuscular radiation, and other physical processes capable of delivering enough uncontrolled energy to interfere with biological processes. The term of biological toxic agents covers parasites, infectious fungi, bacteria and viruses, as well as toxins produced by infectious organisms in vivo. Chemical toxic factors cover the field in-between, with significant overlaps. An example from the physics/chemistry borderline is provided by radioactive elements introduced into the organism. They generally act as sources of highly energetic photons and particles, which elicit cascades of ionizing radiation intermediates. Their actual toxicities will, however, depend on their biodistribution, which in turn depends on their non-radiative, chemical properties.

Moreover, many radioactive elements, uranium for example, are definite chemical poisons as well [1]. Toxins present in venoms of such organisms as marine snails or snakes serve as an example from the biology/chemistry borderline. These toxins have an obvious biological origin and are introduced into their victims by a definitely biological act of stinging or biting. From this moment, however, they act solely by the virtue of their chemical properties.

In molecular terms toxic agents can be divided into organic poisons (such as ethylene glycol, sarin, strychnine) and inorganic poisons (such as chlorine, cyanide, phosgen). The latter ones are distinguished somewhat formally by the absence of carbon-carbon bonds. In this simplistic classification, toxins produced by living organisms generally, but not exclusively, belong to the organic chemistry realm. Proteins (e.g. botulinum toxin or ricin) or alkaloids (e.g. atropine or tubocurarine) are typical organic toxins, but, for example, the toxicity of cyanogenetic glycosides, such as amygdalin, is due to the release of a classical inorganic poison, hydrogen cyanide, from their molecules upon the action of $\beta$-galactosidase. 
Toxic metal ions have a specific property that differentiates them from all other poisons. Inorganic or organic toxins are multiatomic molecules, which, at least in principle, can be detoxicated by chemical modification, in particular by decomposition into non-toxic derivatives. A toxic metallic element cannot be transmuted into another, non-toxic one by biological means. (Transmutation is an alchemy term for changing lead into gold. In modern terms transmutation is equivalent to nuclear reaction which can be accomplished in a controlled fashion in an accelerator, and nuclear explosion is an example of uncontrolled transmutation). Therefore, the means of defense against toxic metal ions are seriously limited, only to immobilization or excretion. Furthermore, a toxic metal ion can act by many molecular pathways. Being indestructible, it can migrate from one interaction with a protein, nucleic acid or small molecule to another. Many toxic metal ions act indirectly, as catalysts facilitating the formation of inorganic or organic toxins.

In this context, we need to make a note regarding two styles of naming partners in such interactions. A biochemical convention uses the term ligand for small molecules, including metal ions, that bind to macromolecules, such as proteins. In coordination chemistry, however, the term ligand is used to label all molecules, big or small, which form bonds with metal ions, assumed to be the center of the complex. The latter convention seems to be more appropriate for describing interactions of toxic metals with biomolecules. Toxic metals usually do not have their specific physiological binding partners (they are not dedicated to macromolecules of any specific kind). Instead, they are "free to choose" - it is their binding preferences and that define toxic interactions.

The toxicity of metal ions is aggravated by the fact that many of them are either absent from the natural environment, or present there in such chemical forms that make them inaccessible for a living system. Such metals are particularly dangerous, when introduced into the environment or mobilized from hitherto safe stores as a result of industrial activity, 
because no defense mechanisms had a chance to evolve against them. Aluminum poisoning of fish in Northeast US and Scandinavian lakes several decades ago, caused by the dissolution of soil aluminosilicates by acid rain of industrial origin is a classical example of such an event $[2,3]$.

Mercury and lead are two very toxic elements, which have been present in human environment in very large quantities, due to their widespread technological usage since antiquity [4]. The increasing awareness of their toxicity, particularly neurotoxicity in children $[5,6]$, led to a gradual withdrawal of these metals and their compounds from materials and objects accessible to general public. Lead was first to made go. Lead metal water pipes (the memory of this technology frozen in the word plumber, from Latin plumbum for lead) and toy soldiers, pigments in paints, such as yellow lead(II) chromate $\left(\mathrm{PbCrO}_{4}\right)$ and white lead(II) carbonate $\left(\mathrm{PbCO}_{3}\right)$, and tetraethyllead additive to gasoline [7] have been gradually vanishing from the human environment in most countries. Somewhat surprisingly, extremely toxic mercury is slower to depart. Recent EU decisions to promote energy saving light sources may even result in the increase of environmental mercury burden. However, such potentially hazardous mercury applications, as amalgam dental fillings [8], spill-prone mercury thermometers, and mercury-containing drug preservatives (sodium ethylmercurithiosalicylate - thimerosal) [9] are being gradually removed from the global market (the latter has been banned in EU since 2001, but is still approved in the USA and many other countries).

The aim of this review is to summarize the current state of knowledge about molecular mechanisms of toxicity of two other, very toxic metals: cadmium and nickel. These two elements are abundant in the human environment, largely due to their applications in the articles of everyday use. The amount of evidence of their toxicity and carcinogenesis at low doses is rising continuously. Health hazards to large communities due to current exposures to 
these two elements are likely. Yet, the awareness of their toxic properties seems to be limited, compared to that related to lead and mercury.

\section{CHEMICAL PROPERTIES AND ROUTES OF EXPOSURE TO CADMIUM AND NICKEL COMPOUNDS}

\subsection{Chemical Properties of Cadmium}

Cadmium, element no. 48 , belongs to the 12 th group of the periodic table (together with zinc and mercury), due to its electron configuration $[\mathrm{Kr}] 4 \mathrm{~d}^{10} 5 \mathrm{~s}^{2}$. Natural cadmium is a mixture of eight isotopes with isotopic masses between 106 and 116. Its standard atomic weight is 112.41 Da. In its elemental metallic form $\mathrm{Cd}$ is soft and malleable at room temperature. It undergoes passivation in contact with oxygen, being covered with a layer of cadmium oxide. Chemistry of cadmium includes $0,+1$ and +2 oxidation states, however, only Cd(II) compounds are stable under ambient conditions. In complexes $\mathrm{Cd}(\mathrm{II})$ coordination numbers vary from 2 to 8 , with 4 (tetrahedral) and 6 (octahedral) being the most frequent ones [10]. The d-electron shell of Cd(II) is filled, therefore, its chemical behavior is similar to that of main group rather than transition metals. $\mathrm{Cd}(\mathrm{II})$ is a moderately soft metal ion, forming particularly strong bonds with thiolates, but can also interact effectively with oxygen and nitrogen donors $[11,12]$. Consequently, $\mathrm{CdS}$ and $\mathrm{CdO}$ are the most important binary $\mathrm{Cd}(\mathrm{II})$ compounds. Thiolate $\mathrm{Cd}(\mathrm{II})$ complexes are tetrahedral, and isostructural with $\mathrm{Zn}(\mathrm{II})$ complexes $[11,13]$. Higher coordination numbers are encountered in oxygen donor environments, by analogy to $\mathrm{Ca}(\mathrm{II})[11]$.

\subsection{Chemical Properties of Nickel}

Nickel, element no. 28 belongs to the 10th group of the periodic table (together with palladium and platinum), due to its electron configuration $[\mathrm{Ar}] 3 \mathrm{~d}^{8} 4 \mathrm{~s}^{2}$. Natural nickel is a mixture of five stable isotopes with isotopic masses between 58 and 64, with 58 and 60 being 
most abundant. Its standard atomic weight is $58.69 \mathrm{Da}$. Elemental nickel is a white metal with a yellowish shade. It is malleable, melts in high temperatures and is ferromagnetic up to $627 \mathrm{~K}$ (Curie temperature for nickel). Metallic nickel is resistant to corrosion in humid air. In chemical compounds nickel can be encountered at oxidation levels from -1 to +4 , but $\mathrm{Ni}(\mathrm{II})$ is by far the most important oxidation level at ambient conditions. Its most common coordination numbers are 4, 5, and $6[10]$. The existence of readily interconvertible high spin and low spin $\mathrm{Ni}(\mathrm{II})$ compounds is the most characteristic feature of $\mathrm{Ni}(\mathrm{II})$ chemistry, because of the accompanying changes of color (Ni(II) termochromism). High-spin Ni(II) complexes are usually octahedral (six-coordinate), the low spin complexes are typically square-planar (four-coordinate). Much less frequent square-pyramidal (five-coordinate) species occur for both high- and low-spin configurations. Ni(II) readily accepts oxygen, nitrogen and sulfur ligands. Harder ligands, like water or carboxylate oxygens, stabilize high-spin complexes, whereas softer donors, like thiolate sulfurs promote the formation of low spin complexes [13].

Low oxidation levels, -1 and 0 , are encountered in organometallic complexes (defined as those containing metal-carbon bonds). The very stable Ni(0) tetracarbonyl is the most important of them. $\mathrm{Ni}(\mathrm{I})$ complexes are very instable in air. This oxidation level is stabilized by thiolate coordination and is known mostly from bioinorganic studies of redox enzymes of anaerobic microorganisms [14]. Ni(III) is a strong oxidant, stabilized by strong nitrogen ligands $[15,16]$. Compounds of the even stronger oxidant, $\mathrm{Ni}(\mathrm{IV})$ are very rare and instable. Characteristically, the spin state of a $\mathrm{Ni}(\mathrm{II})$ complex controls its redox properties: the $\mathrm{Ni}(\mathrm{I})$ and $\mathrm{Ni}(\mathrm{III})$ state are accessible only from the low-spin complexes, while $\mathrm{Ni}(\mathrm{IV})$ complexes can only be obtained from high-spin species [17]. This phenomenon is due to Jahn-Teller effect, which precludes the octahedral geometry for d-electron configurations of $\mathrm{d} 7$ and $\mathrm{d} 9$, corresponding to $\mathrm{Ni}(\mathrm{III})$ and $\mathrm{Ni}(\mathrm{I})$, respectively.

\subsection{Exposures to cadmium}


Cadmium is widespread in the natural environment at low levels, comprising ca. $1.5 \times 10^{-5} \%$ of the Earth crust. It accompanies mainly zinc, and also calcium (e.g. otavite, $\left.\mathrm{CdCO}_{3}\right)[18,19]$. Grenockite, $\mathrm{CdS}$, the most important specific cadmium mineral, is very rare in nature, and industrial cadmium is obtained as a by-product of refinement of copper and zinc. Cadmium is not considered to be essential for life in general. However, an interesting exception is provided by marine diatoms grown under zinc deficiency. The addition of Cd(II) can restore growth in these organisms, apparently by taking up key enzymatic functions of $\mathrm{Zn}(\mathrm{II})$, including that in carbonic anhydrase $[20,21]$. As mentioned above, due to chemical similarities with $\mathrm{Ca}(\mathrm{II}), \mathrm{Cd}(\mathrm{II})$ is sometimes present in limestone soils and often accompanies phosphates. Several anthropogenic sources of Cd(II) are relevant for the general population. Large-scale burning of materials containing cadmium is one of them. Energetic coal burning spreads very fine dusts and ashes containing cadmium oxide and inorganic salts over large areas [22]. There is, however, a very large variation of cadmium contents depending on geological origin of the solid fossil fuel [23]. Municipal solid waste incinerators (MSWI) appear to be important sources of cadmium enriched fly ash. Their overall emissions are much smaller, than the energetic ones, but MSWI are often located close to human settlements [24]. The speciation of cadmium in MSWI fly ashes is more complex, with "hot-spots" made of water soluble, and thus readily bioavailable cadmium halides and sulfate $\left(\mathrm{CdCl}_{2}, \mathrm{CdBr}_{2}\right.$, $\mathrm{CdSO}_{4}$ ), accompanied by less bioavailable cadmium silicate, oxide and metallic cadmium [25-27]. Further sources include phosphate fertilizers, which may contain up to $0.01 \%$ of cadmium, depending on the geological source of the phosphate [28], and calcium carbonate used for recultivation of acidified soils and waters (however, the liming process may actually reduce bioavailability of cadmium from natural acid soils [29]). Industrial emissions of cadmium are related to its usage in the manufacturing of Ni-Cd accumulators, pigments, alloys (addition of Cd lowers the melting point) and organic polymers (e.g. $\mathrm{Cd}(\mathrm{II})$ compounds 
are used as stabilizers in plastics such as PVC). Some plants, including tobacco, are efficient $\mathrm{Cd}(\mathrm{II})$ bioaccumulators. As a result, tobacco smoking is perhaps the most relevant source of cadmium exposure to persons not exposed occupationally [30]. Both first-hand and second-hand smoke is dangerous, as air exhaled by a smoker is enriched in cadmium [31].

Accumulation in farm animals is strongly organ-specific, with kidney as a prime target [32]. Doses of cadmium at the level of $1-3 \mu \mathrm{g}$ Cd per day approximately, ingested with food and drink in industrialized areas, such as European Union, are not considered hazardous [33, 34]. However, the bioavailability of food cadmium depends on a person's nutritional status. The intestinal absorption of cadmium, generally proportional to the concentration in the diet, is reduced, if the nutritional status of zinc, iron or calcium of a person is high, and correspondingly, the low general nutritional status of these metals enhances cadmium absorption [34]. A significant consumption of specific foods may affect both factors. For example, rice accumulates cadmium into grain, when available, but excludes zinc, even when grown on soils rich in zinc. Consumption of such rice leads to zinc/iron malnutrition and increase of cadmium intestinal absorption and accumulation. On the other hand, the consumption of foods rich in cadmium, iron and zinc, such as seafood, does not increase cadmium absorption [35]. This fact is especially important with respect to premenopausal women, who commonly have low body iron stores [35]. Recent studies indicate that divalent metal transporter-1 (DMT-1) is partially, but not exclusively responsible for increased cadmium absorption in the presence of a nutritional deficit of other metal ions transported by DMT-1 [36].

Occupational exposures to cadmium relevant to human health are mainly of respiratory nature, and are related to mining or manufacturing of batteries and pigments. The 
average consumption of cadmium with tobacco smoke, $\sim 1-3 \mu \mathrm{g}$ of $\mathrm{Cd}$ per pack of cigarettes

is considered to be of a higher toxicological importance. The cadmium turnover in the human

body is slow, with a biological half-life of $\sim 10-20$ or more years, significantly higher in

women [37, 38]. Consequently, cadmium tends to accumulate in human body with age, and heavy smokers accumulate significantly more cadmium than non-smokers [37-39]. Also, the environmental exposure in childhood aggravates the cadmium status in adults [40].

\subsection{Exposures to nickel}

Nickel is widespread in the environment at levels generally higher than those of cadmium. It comprises $0.0084 \%$ of the Earth crust, existing mostly as soluble salts (sulfate, chloride etc.) and insoluble compounds (sulfides, oxide). Major ores of nickel include pentlandite $(\mathrm{Fe}, \mathrm{Ni})_{9} \mathrm{~S}_{8}$ accompanied by other sulfide minerals, and excavated e.g. in the world largest deposits in Sudbury in Canada, Norilsk in Russia and most other mining sites, except of New Caledonia, where garnierite (hydrous nickel silicate, $(\mathrm{Ni}, \mathrm{Mg})_{3} \mathrm{Si}_{2} \mathrm{O}_{5}(\mathrm{OH})$, ores are exploited. Higher soil Ni(II) levels are encountered locally, due to particular geological conditions and in the areas of nickel ore mining and smelting, such as Sudbury [41].

Nickel-containing cofactors are crucial components of several enzymes key to metabolism of archaeons and anaerobic bacteria, providing redox chemistry for functions 
such as energy generation and utilization, akin to those assumed by copper enzymes in aerobic organisms [14]. Nickel is also essential for legumes, and some other higher plants, and for many species of aerobic bacteria and fungi, for another reason. Two Ni(II) ions constitute the active site of ureases, a unique class of non-redox enzymes breaking down urea to ammonia, which is an appropriate nitrogen source for plants [42, 43]. Apart from this specific usage, $\mathrm{Ni}$ (II) is bioaccumulated in some plant foods, such as spinach, cocoa and nuts [44]. Tobacco also accumulates Ni(II).

The literature provides conflicting data on the extent of intestinal absorption of $\mathrm{Ni}(\mathrm{II})$ salts, from as low, at $1-5 \%$ of the dose to as high as $20-25 \%$ [45-47]. The nutritional status and mode of administration seem to be crucial in this respect. The urinary elimination of $\mathrm{Ni}(\mathrm{II})$ is rather rapid - with a half-life of approximately a couple of days [48]. A high proportion of ingested $\mathrm{Ni}(\mathrm{II})$ is removed from human body with urine within several days. Oppositely to cadmium, the retention of nickel is lower in women than in men, by a factor of two [49]. Oral exposure to low doses of $\mathrm{Ni}(\mathrm{II})$ compounds is not considered to be hazardous. This notion is supported by animal experiments [50]. However, a prolonged elevation of respiratory cancer risk in retired nickel refinery workers, has been related to continuous presence of accumulated $\mathrm{Ni}(\mathrm{II})$ in their airways $[51,52]$. The clearance of insoluble $\mathrm{Ni}(\mathrm{II})$ compounds is about 10 times slower than that of soluble compounds [53].

Nickel is listed in many textbooks as an essential microelement in humans, on the basis of experiments on animals fed on nickel-deficient diets (reviewed in [54]). The lack of specificity of effects observed, seems to be associated with an absence of any nickel-specific physiological process in animals, including humans. In contrast, many bacteria, including the notorious Helicobacter pylori, which causes peptic ulcers, require $\mathrm{Ni}$ (II) for urease, which is similar to that described above [55]. The opinion that nickel is required by (not necessarily beneficial) bacteria inhabiting our digestive tracts, rather than ourselves, was expressed some 
time ago [54]. We are not aware of any new facts that could challenge it. On the contrary, all recent research, reviewed below, provides evidence for toxic effects of $\mathrm{Ni}(\mathrm{II})$ in human body.

Major industrial uses of nickel include stainless steel and other alloys. White nickel alloy with copper $(75 \% \mathrm{Cu}, 25 \% \mathrm{Ni})$, other $\mathrm{Cu}-\mathrm{Ni}$ and $\mathrm{Cu}-\mathrm{Ni}-\mathrm{Zn}$ alloys, and sometimes even pure metallic nickel are used worldwide for coin production. Other uses of Ni include nickel plating of corrosion-prone metals, such as iron, manufacturing of Ni-Cd batteries, and nickelbased catalysts, including those for industrial hydrogenation processes (such as that of edible oil) and carbon nanoparticle manufacturing.

Occupational exposure to nickel compounds is mostly respiratory, similarly to cadmium. It is associated with nickel mining and refinement, electroplating, metallurgy of nickel-containing alloys and stainless steel welding. Another type of respiratory exposure, affecting the general public, is due to residual fly ash containing bioavailable $\mathrm{Ni}(\mathrm{II})$ compounds [56]. There are two types of such ash. Residual oil fly ash (ROFA) is generated in the course of combustion of heavier fractions of oil products in Diesel car engines and power plants. Its nickel contents can be as high as $1.5 \%$ [57], and the resulting air level of nickel in large cities and industrial areas is increased by a factor of ten to twenty, compared to suburban areas [58]. Some coal burning electric power plants and MSWI also emit fly ash containing significant amounts of nickel $[59,60]$. The presence of nickel in oil and coal reflects its physiological functions in anaerobic bacteria and plants, respectively. Nickel is present in ROFA predominantly as water-soluble $\mathrm{NiSO}_{4}$, with varied amounts of insoluble salts, including little or no sulfides [57, 61]. In contrast, other types of fly ash contain mainly nickel oxide and sulfides, followed by insoluble Ni(II) compounds and metallic nickel, and generally little amounts of $\mathrm{NiSO}_{4}[60,62]$. Nickel is bioavailable from ROFA to airways and may be partially responsible for acute toxic effects of ROFA inhalations, as determined using experiments on cell lines and laboratory animals [63-68]. These studies point, however, 
towards vanadium(IV) and vanadium(V) compounds, which always accompany nickel in ROFA, as the major source of direct oxidative damage to cells, observed as a result of acute exposure.

\section{HEALTH HAZARDS DUE TO EXPOSURES TO CADMIUM AND NICKEL COMPOUNDS}

\subsection{Health hazards related to cadmium exposure}

Nephropathy associated with the characteristic cadmium proteinuria is the most prevalent result of cadmium intoxication, observed for all routes and modes of exposure [69, 70]. Acute cadmium intoxications are rare and confined to occupational accidents. Acute respiratory exposure to airborne cadmium or cadmium oxide gives symptoms of cadmium fever, similar to that of much more common zinc fever but much more persistent, due to a slow clearance of $\mathrm{CdO}$ from the lung tissue. However, for cadmium, such exposure may also result in lung fibrosis, atherosclerosis of pulmonary arteries, and nephropathy [71]. Acute oral poisoning may evoke circulatory insufficiency [72]. Major health hazards of chronic respiratory exposure to cadmium include carcinogenesis in respiratory tract and internal organs, as well as reproductive disorders, such as derangement of spermatogenesis and impairment of hormonal balance [73-75]. Osteoporosis is a very characteristic effect of chronic oral intake of large doses of soluble cadmium compounds, accompanying nephropathy $[76,77]$. The itai-itai disease was described in Japan in areas heavily polluted with cadmium-rich industrial waste. This condition affected mostly post-menopausal women, prone to osteoporosis. Despite a rather weak ability of cadmium to substitute calcium in bones directly, at levels 30 -fold lower from those detected in the liver, the significant bone mass loss occurred. This led to the loss of the bone resistance to weak mechanical stress and multiple recurring fractures. The mechanism of this process is likely based on the interference with calcium metabolism in bone remodeling cells - osteoblasts and osteoclasts [76]. The 
improved environmental protection makes itai-itai largely a historical condition. Notably, long-term Japanese studies indicated that there was no elevation of cancer incidence in populations suffering long-term exposure to environmental cadmium [78].

\subsubsection{Cadmium nephropathy}

Kidneys are the main and ultimate cadmium target in the human body. This feature of cadmium toxicity is seen most clearly in chronic exposures to low levels of cadmium, which are most relevant to the general public. Cd(II) nephrotoxicity is observed with no regard to the intake route, be it oral or respiratory. It is characterized by a specific form of proteinuria, which manifests itself clinically upon a prolonged duration of exposure, typically of twenty years or more [79]. Tubular reabsorption impairment in kidneys results in the appearance of low molecular weight proteins and metabolites in urine, while glomerular dysfunction leads to the leakage of high molecular weight proteins $[79,80]$. The proteinuria is generally irreversible, despite of the cessation of exposure, except for very mild cases. This fact is related to the very long biological half-life of cadmium, mentioned above [37, 38]. The renal abnormalities are accompanied by elevated Cd(II) levels in the kidney tissue. The element is then also present in urine [80-82].

There is a threshold level for cadmium in the renal cortex, above which the tubular damage occurs. The older data indicated the threshold value of approximately $200-250 \mathrm{ppm}$ [81]. Now the limit has been lowered to ca. 150-200 ppm [83]. The levels of cadmium in whole blood, kidney, liver and urine of exposed subjects are correlated, signifying high mobility of cadmium among the compartments of human body. Cd(II) is transported to kidney as a complex with metallothionein (MT), a metal ion storage protein. The exchange of this complex between kidney and liver is thought to be responsible for the paradoxical lowering of 
kidney cadmium burden along with the progression of renal dysfunction [84]. There are, however, no epidemiologic data that would link cadmium intoxication with liver disease.

Recent studies indicate that cadmium exposure may be linked to diabetic nephropathy, and to diabetes itself. Epidemiology suggests that the body $\mathrm{Cd}(\mathrm{II})$ burden may exacerbate kidney damage due to diabetes, and diabetes may aggravate cadmium nephropathy. Animal studies confirm these observations and demonstrate a direct action of $\mathrm{Cd}$ (II) on Langerhans islets, resulting in the pancreatic cadmium accumulation and decrease of blood insulin [85]. These results suggest that cadmium toxicity is more widespread and more severe in broad populations than hitherto estimated.

\subsubsection{Reproductive disorders due to cadmium exposure}

Exposure to cadmium causes reduced male fertility (reduced sperm count, and poor semen quality), disruption of blood-testes barrier (BTB), germ cells loss, testicular edema, hemorrhage, necrosis, and, eventually, sterility [86]. In women cadmium influences oocyte maturation, oocyte pick-up and development of the pre-implantation embryo, which have obvious clinical implications. As mentioned above, tobacco smoke is one of the main sources of cadmium in the human organism. Consequently, the concentration of $\mathrm{Cd}(\mathrm{II})$ in the follicular fluid of female smokers undergoing in vitro fertilization was reported to be elevated by $15 \%$ compared with non-smokers [87]. Elevated Cd(II) levels have also been associated with a higher risk of ectopic pregnancy and with recurrent miscarriages. Cadmium exposure is also teratogenic [87].

The reproductive toxicity of $\mathrm{Cd}(\mathrm{II})$ is largely related to its hormone mimicking activity. Cadmium binds to estrogen (ER) and androgen (AR) receptors. Ovariectomized female rats exposed to cadmium showed increase of the uterus weight and increased growth

of mammary glands. The effects were suppressed by administration of an antiestrogen [88]. In 
castrated rat males, $\mathrm{Cd}(\mathrm{II})$ had an androgenic effect also suppressed by administration of the antiandrogen. Therefore, the data suggest that cadmium is a potent endocrine disruptor acting via binding to hormone receptors [88]. Recent cell line experiments also provide evidence for the interference of $\mathrm{Cd}(\mathrm{II})$ with estrogen receptor related signal transduction pathways [89].

\subsubsection{Cadmium and COPD}

Chronic obstructive pulmonary disease (COPD) is a life threatening disorder of pandemic proportions, considered as one of the major global causes of morbidity and mortality [90]. COPD involves small airways disease, mucus hypersecretion, and chronic bronchitis, which lead to the progressive impairment of lung function, decrease of airflow and shortness of breath The disease, clearly associated with smoking, is likely to have multiple triggering factors, related to the exposure to environmental pollutants, including metal ions [91]. There is also evidence for the relationship of COPD with the occupational exposure to metals [92]. Exposure to cadmium, measured by urinary cadmium excretion, has recently been correlated with the severity of pulmonary function decrease, and there is mouting evidence for the causative relationship between the cadmium exposure and COPD [93, 94].

\subsubsection{Cadmium carcinogenesis}

The World Health Organization's International Agency for Research on Cancer (IARC) rates chemical elements and compounds according to their carcinogenicity. Group 1 includes confirmed human carcinogens, and groups $2 \mathrm{~A}$ and $2 \mathrm{~B}$ include substances assigned as probable and possible carcinogens, respectively. Group 3 contains chemicals declared noncarcinogenic according to the current state of knowledge [95]. Cadmium and its compounds were declared as definitely carcinogenic (Group 1) in 1993, on the basis of substantial epidemiological evidence of lung cancer incidence in workers exposed occupationally to cadmium-containing fumes [74]. These data were complemented by the abundant evidence of 
pulmonary adenocarcinomas in rats which inhaled either soluble cadmium chloride aerosols or insoluble cadmium oxide fumes $[96,97]$. Occupational and non-occcupational cadmium exposure has also been implicated in the etiology of transitional cell carcinoma of the urinary bladder [98, 99]. Smoking-related cadmium seems to be responsible for the most, or even all excess risk of this cancer $[100,101]$. These epidemiological studies are supported by cell culture studies, which demonstrate the ability of $\mathrm{Cd}(\mathrm{II})$ ions to directly cause the malignant transformation of bladder epithelial cells [102].

Weaker, but still accumulating evidence is available for the causative involvement of cadmium in carcinogenesis in several other human organs. While epidemiological studies of prostate cancer etiology yielded conflicting results with respect to cadmium [103], animal and cell culture studies support the involvement of cadmium in the development of prostate adenocarcinoma [96, 104-106]. Results of a recent analytical study indicate that the cadmium accumulation does not differentiate the prostatic cancer from the benign prostatic hyperplasia (BPH), both significantly elevated above the control level, but suggest that the elevated MT level, observed specifically in BPH could provide protection against malignancy [107].

The incidence of pancreatic cancers is related to cigarette smoking, chronic pancreatitis, diabetes and occupational exposures to toxins and heavy metals. Cadmium is represented in the first and the last of these factors, and has been implicated in the etiology of diabetes and diabetic nephropathy $[85,108]$. A significant increase of blood cadmium was also recorded in pancreatic cancer patients [109]. These coincidences warrant further studies within this research area, which is very important due to the extreme malignancy and very low survival ratio in pancreatic cancer patients [110].

Renal cancer also seems to be associated with occupational exposure to cadmium $[111,112]$. The nephropathy develops into kidney cancer rarely, indicating a requirement for 
additional causative factors for the latter to occur. Per analogy with prostate, is seems likely that cadmium carcinogenesis in kidney also depends on the intracellular level of MT.

Interestingly, cadmium has not been demonstrated directly to cause breast cancer, in spite of its estrogen mimicking activity, which seems to predestinate it to such an ability. This striking contradiction has been ascribed to antiangiogenic properties of $\mathrm{Cd}(\mathrm{II})$ [113]. On the other hand, epidemiological studies indicate an association between the increased incidence of breast cancer and occupational cadmium exposure [114]. Also this area of research can be expected to grow rapidly, due to the populational significance of breast cancer.

Recently, an epidemiological correlation of long-term non-occupational cadmium exposure with a slightly increased risk of endometrial cancer was demonstrated in postmenopausal women [115]. An association of this fact with hormone-mimicking cadmium activity is very likely.

\subsection{Health hazards related to nickel exposure}

Health effects exerted by exposure to nickel and its compounds can be subdivided into three major groups: acute toxicity related to respiratory or oral exposure, carcinogenesis in respiratory organs, resulting from chronic inhalation of nickel compounds, and nickel allergy, related to dermal and oral exposure. Other health hazards include hard metal asthma, which has a nickel-specific component [116] and teratogenicity, observed in extreme industrial exposures, but not pronounced at lower exposures near nickel refineries [117, 118].

\subsubsection{Acute nickel toxicity}

Nickel tetracarbonyl $\mathrm{Ni}(\mathrm{CO})_{4}$ is a nickel compound responsible for the majority of known cases of acute nickel toxicity. It is a gas formed upon the direct reaction of $\mathrm{CO}$ (carbon monoxide) gas with metallic nickel, used for obtaining very pure nickel for industrial 
applications in Mond process [119]. Human exposure to $\mathrm{Ni}(\mathrm{CO})_{4}$ occurs only occupationally, as a result of rare industrial accidents $[120,121]$. The immediate symptoms include respiratory tract irritation and headache, followed by an asymptomatic period and delayed pulmonary symptoms similar to a pneumonia, accompanied by cardiological and cerebral problems. Depending on the dose and individual susceptibility, the exposures may be deadly, and in the survivors the long term neurasthenic syndrome and weakness may last for as long as six months [121]. On the other hand, the accidental ingestion of water containing a high concentration of soluble $\mathrm{Ni}$ (II) salts by a group of workers resulted in transient symptoms, largely of gastrointestinal character. No long-term health problems were detected in this group [122].

\subsubsection{Nickel allergy}

Nickel is the most frequent of all allergens causing allergic contact dermatitis [123]. Consequently, nickel allergy is a worldwide health problem. It affects one of every six persons on average. Women exhibit hypersensitivity to nickel four times more frequently than men [124]. This prevalence is currently thought to result from the frequent childhood exposure of women to nickel containing fashion jewelry [125]. European Union acknowledged nickel allergy to be a major social health problem for European societies and issued a directive posing limits on nickel release from materials coming into prolonged contact with skin [126]. In the light of recent epidemiological data indicating the increase of incidence of nickel hypersensitivity in general population, and particularly in children in North America, a similar regulation has been proposed for the USA [127-129]. Allergic contact dermatitis to nickel (Ni-ACD) is the most frequent clinical manifestation of nickel allergy, but general allergic symptoms, like conjunctivitis, rhinitis, bronchial asthma, or disseminated eczema are also prevalent. There is no medication available, and the only way to alleviate the symptoms is to avoid contact with objects made of stainless steel and other 
nickel-containing alloys, including tools, door handles, some arts of silver jewelry, coins and many others. Coins in particular are difficult to avoid, and they are usually made of alloys with high $\mathrm{Ni}(\mathrm{II})$ content. The common name "nickel" for the American 5 cent coin made of the typical $75 \% \mathrm{Cu}, 25 \% \mathrm{Ni}$ alloy is indicative of a long history of this issue, but it was Euro coins, which contain the same alloy in their white parts and a 5\% Ni alloy in their yellow parts, that attracted public attention more recently $[130,131]$. A severe manifestation of nickel allergy has therefore obvious deleterious consequences in life and work, and there is urgent need for active remedies against this disease.

\subsubsection{Nickel Carcinogenesis}

Carcinogenicity of nickel was first reported in the occupational context, and solid medical evidence on incidence of cancer resulting from nickel exposure remains to be largely associated with workplace exposure $[54,132,133]$. The first reports regarded rather spectacular cancers of the nasal cavities in workers employed in a nickel refinery (Mond Nickel Works in Clydach, Wales), soon to be complemented with lung cancers [134]. The incidence of malignancies was horrific: $35.5 \%$ of employees died of these cancers, as compared to $1.5 \%$ incidence in coal miners [135]. In the light of these findings, nickel-related cancer of upper and lower airways has been the first officially recognized occupational disease, in Great Britain and worldwide $[132,133]$. The locations of malignancies clearly suggested the inhalatory route of exposure. Subsequent epidemiological studies confirmed exposure to airborne $\mathrm{Ni}$ (II) compounds as the cause of cancer in chronically exposed individuals $[136,137]$. Dusts containing insoluble compounds, mostly $\mathrm{Ni}_{3} \mathrm{~S}_{2}, \mathrm{NiS}$, and $\mathrm{NiO}$, as well as aerosols of soluble $\mathrm{Ni}$ (II) salts bear a risk of cancer, confirmed by the IARC assignment of these compounds as confirmed (Group 1) human carcinogens. Metallic nickel dusts are currently rated as possibly carcinogenic to humans (IARC Group 2B) [132]. 
There is no single type of tumor resulting from inhalatory Ni(II) exposures. A careful histopathological study of a large number of respiratory tract tumors developed in nickel refinery workers in Wales, Canada, and Norway indicated a prevalence of squamous cell carcinomas, followed by a number of other carcinomas, with a small incidence of adenocarcinomas and several other tumor types [138].

The location of tumors within airways was found to be related to the size of nickelcontaining particles, due to their ability to penetrate the airways. The largest, millimeter size grains are deposited in the nose and mouth, while the finest of micrometer and smaller sizes can penetrate all the way down to the lungs [139].

While causative relations between nickel exposure and other malignancies, e.g. larynx, kidney, prostate, and stomach carcinomas and soft-tissue sarcomas were suggested, they have not been demonstrated in humans in a statistically relevant fashion [133]. On the other hand, there is some evidence for such malignancies in laboratory animals, as reviewed [54, 133]. Nickel compounds induce local tumors at virtually all sites of application. Water-insoluble sulfides and oxide are more active than soluble salts, which is due to a rapid clearance of soluble $\mathrm{Ni}(\mathrm{II})$ compounds from the site of application [140, 141]. Interestingly, intraperitoneal injections of soluble $\mathrm{Ni}(\mathrm{II})$ acetate resulted in both local and distant tumorigenesis, including lung tumors in strain A mice and renal cortical adenomas in F344 rats, the latter, when accompanied by a prolonged administration of sodium barbital, a cancer promoter [142, 143]. Intraperitoneal administration of $\mathrm{Ni}(\mathrm{II})$ acetate in pregnant $\mathrm{F} 344$ rats produced pituitary (without barbital) and renal (with barbital) tumors [144]. As mentioned above, the administration of soluble $\mathrm{Ni}(\mathrm{II})$ salts in drinking water did not yield tumors in experimental animals [50]. 
A phenomenon of transgenerational, paternally inherited carcinogenesis was noted in epidemiological studies of children whose fathers were occupationally exposed to toxic metal mixtures (e.g. welders) [145]. Nevertheless, the direct association of this rare phenomenon with exposure to nickel specifically, however likely, seems premature at this moment.

Endoprostheses and other implantable surgical devices made of nickel-containing alloys have been suspected to cause tumors locally due to nickel leaking by corrosion in body fluids $[133,146]$. The evidence has not been ruled conclusive, but convincing enough to assign these implants to Group 2B by IARC [147]. These alloys have been subsequently phased out in favor of alloys based on metals considered non-carcinogenic, ceramics, or materials coated with biocompatible organic polymers.

As mentioned above, general populations are exposed to nickel compounds in food, tobacco, and urban air. These exposures have not been considered to pose nickel-specific health hazards, as no direct epidemiological evidence for such is available. Nevertheless, the combination of facts reviewed briefly above suggests that such analysis might be worthwhile. In particular, the chemical forms of nickel in inhaled particulate matter, such as ROFA, are sufficiently similar to those considered carcinogenic in the occupational setting. Of course, doses of nickel inhaled occupationally are much higher than the environmental ones. The levels of total nickel in lung wet tissue were found to be higher than controls by a factor of $112-5800$ in nickel refinery workers and by a factor of 500 in stainless steel welders [148, 149]. However, the populations exposed are about as much bigger, and huge differences in individual susceptibilities to nickel carcinogenicity are evident. Further studies are definitely required to clarify the issue of environmental hazard of airborne nickel, but this issue should not be neglected, as stated already fifteen years ago by Canadian Environmental Health Directorate [150]. 


\section{MOLECULAR MECHANISMS OF CADMIUM AND NICKEL TOXICITY}

\subsection{Molecular Mechanisms of Cadmium Toxicity}

The molecular toxicology of cadmium is an interplay between extracellular transport phenomena, which govern the distribution of this metal in the organism and intracellular interactions, predominantly involving proteins. The following paragraphs cover three major areas of cellular and molecular research in this area: metallothioneins and cadmium redistribution, mechanisms of cadmium carcinogenesis, and effects of cadmium on cellular junctions.

\subsubsection{Metallothionein and extracellular transport of $\mathrm{Cd}(\mathrm{II})$ ions}

Both inhalatory and gastrointestinal ways of exposure to cadmium yield, eventually, $\mathrm{Cd}(\mathrm{II})$ ions into the bloodstream. Albumin is a major cadmium binding protein of human serum, capable of simultaneous binding of two Cd(II) ions $[151,152]$. Other proteins, including transferrin and $\alpha$-2-macroglobulin were also implicated in blood transport of cadmium on the basis of in vitro experiments and animal studies $[153,154]$. These proteins bind $\mathrm{Cd}(\mathrm{II})$ ions with their oxygen and nitrogen donors, despite the preference of $\mathrm{Cd}(\mathrm{II})$ ions for thiol ligands. This is due to a low availability of thiol ligands in the bloodstream. The resulting binding is in the micromolar affinity range, enabling facile and rapid (in a minutes to hours timescale) transport of $\mathrm{Cd}(\mathrm{II})$ ions to the liver [155]. Two pathways of further $\mathrm{Cd}(\mathrm{II})$ transport are known. Intracellularly, Cd(II) spontaneously forms relatively strong complexes with reduced glutathione (GSH, $\gamma$-Glu-Cys-Gly) $[156,157]$. The $\mathrm{Cd}(\mathrm{GSH})_{2}$ complex is a molecular mimic of glutathione disulfide (GSSG) and is exported out of the cell along with GSSG, through the ABC transporter system [158]. In liver, this pathway results in the secretion of cadmium into the bile, and its transfer down the digestive tract. This cadmium fraction is largely excreted with the feces, as cadmium reabsorption in the gut is low [159]. 
An alternative pathway includes the Cd(II) binding to metallothioneins (MTs). MTs are a family of small proteins of ca. 60 amino acids, very rich in cysteines (20 residues), involved in intracellular storage and buffering of $\mathrm{Zn}(\mathrm{II})$ and $\mathrm{Cu}(\mathrm{I})$ ions $[160,161]$. There are three major human MTs: MT1, MT2 and MT3. The former two are expressed in many organs, including the liver and kidney, MT3 is brain-specific. The Zn(II)-saturated MT contains seven metal ions, forming two metal-sulfur clusters: $\mathrm{Zn}_{3} \mathrm{~S}_{9}$ and $\mathrm{Zn}_{4} \mathrm{~S}_{11}$. The recent detailed study on $\mathrm{Zn}$ (II) binding to MT2 revealed that the binding is fully cooperative and stronger for the fourzinc domain, while the three-zinc domain demonstrates less-cooperative and weaker interactions [162].

The $\mathrm{Cd}(\mathrm{II})$ binding to MT is nearly isostructural with the $\mathrm{Zn}(\mathrm{II})$ binding, and mixed $\mathrm{Zn} / \mathrm{Cd}$ forms are known to exist in vivo [163, 164]. Cd(II) ions induce expression of MT1 and MT2 in hepatocytes, so that a 24 hour pretreatment with subtoxic cadmium doses protects liver from injury due to a subsequent treatment with a higher dose of $\mathrm{Cd}(\mathrm{II})[165,166]$. The resulting cadmium metallothionein (Cd-MT) is stored in the hepatocyte cytosol, preventing injury to cellular organelles. Such cadmium is not prone to induce apoptosis or necrosis, but can impair DNA repair (see below) [167]. The net result of Cd-MT storage is positive anyway, as poor MT expression was demonstrated to enhance cadmium carcinogenesis [168]. It is very interesting to note that MT expression is very highly variable in humans. Differences between individuals in a given population in hepatic MT expression are very large, up to a factor of 50 or $100[169,170]$. Genetic variability in the promoter region of MT2A gene was recently discussed as a possible source of this effect [170].

Small portions of liver bound Cd-MT can be released back to circulation from damaged hepatocytes, upon prolonged exposure, resulting in the slow decrease of liver cadmium burden $[77,171]$. The tight binding of $\mathrm{Cd}(\mathrm{II})$ ions to MT prevents their unspecific leakage, and there is little uptake of Cd-MT in most tissues. The epithelial cells of the S1 
segment of kidney proximal tubules, however, absorb these complexes, which pass kidney glomeruli due to their low molecular weight of ca. $7 \mathrm{kDa}$. This scenario was considered to be responsible for cadmium nephropathy, and supported by nephrotoxicity observed in rats receiving transplants of cadmium-loaded livers [172]. Studies on MT-null mice and renal cell culture experiments demonstrated, however, that $\mathrm{CdCl}_{2}$ is much more toxic that $\mathrm{Cd}-\mathrm{MT}$ in kidney cells [173-175]. The exact molecular mechanism of cadmium nephropathy remains, therefore, to be elucidated [165].

\subsubsection{Cadmium carcinogenesis: oxidative stress and DNA repair inhibition.}

As mentioned above, cadmium, in the form of $\mathrm{Cd}(\mathrm{II})$ compounds, is one of the most potent metallic carcinogens [74]. Several molecular mechanisms apparently coexist in cadmium carcinogenesis, including oxidative stress, inhibition of DNA repair and apoptosis, and alterations of gene expression. Also, some of these mechanisms are more important than others in specific cell types.

Oxidative stress has been proposed to be a unifying theme, manifesting itself in other mechanistic trails listed [176]. It is a common feature of metal carcinogenesis [177].

However, unlike arsenic, nickel and chromium, the redox silent cadmium is unable to oxidize biomolecules or to catalyze the formation of reactive intermediates. Therefore, indirect

mechanisms must be involved. Furthermore, cadmium is only weakly genotoxic, and typical results of direct oxidative damage to DNA, such as strand breaks or 8-oxo-dG formation were detected only at high micromolar levels of intracellular Cd(II) ions [178, 179]. Other mechanisms of cadmium carcinogenesis manifest themselves at much lower cadmium exposures, which makes them more relevant at realistic long term cadmium exposures in humans [180]. 
Depletion of GSH and (partially interdependent) impairment of mitochondrial control of ROS production seem to be the most important indirect pathways of oxidative stress induction by cadmium. However, the induction of antioxidant MT $[165,166]$ and activation of GSH synthesis $[179,181]$ occur very early in response to cadmium exposure, and these effects need to be overcome for the oxidative stress to ensue. The interplay of these pro- and antioxidative processes appears to be relevant for apoptosis-related cadmium carcinogenesis.

Apoptosis is a frequent result of cadmium exposure in cell cultures. Both caspase dependent and independent mechanisms were reported $[182,183]$, with oxidative stress as a likely common origin of the process [184]. This concept is supported by antiapoptotic effects of antioxidants in cadmium exposure [185]. On the other hand, cadmium has been frequently reported to inhibit apoptosis induced by other toxins, thereby serving as a co-carcinogen [186, 187]. One way to explain this apparent contradiction was provided by the observation that cadmium exposure of RWPE-1 prostate cell cultures resulted in the selection of a subset of cells, which were apoptosis-resistant due to the elevation of MT content [188]. The prevention of apoptosis is considered to facilitate accumulation of DNA lesions in surviving cells, leading to malignant transformation [176]. What is very important, individual elements of these overall mechanisms may be enhanced or suppressed in response of various cell types to cadmium exposure. For example, testicular toxicity of cadmium in various strains of mice was reported to be independent of the relative MT contents [189].

Low level (submicromolar) cadmium exposures result in alterations in gene expression patterns, which are clearly cell type-specific [176]. Oxidative stress and ROS production are implicated in many of these phenomena, including overexpression of proto-oncogenes, such as $c$-fos, $c$-jun, and others [190-192], and inhibition of expression of tumor suppressors, such as $p 53$ [188]. More research is required to elucidate the cause-effect patterns involving these phenomena. 
DNA repair inhibition emerges as a major molecular mechanism in cadmium carcinogenesis, explaining the apparent contradiction between weak mutagenicity and strong cocarcinogenicity of cadmium. There are four major DNA repair systems in mammalian cells: mismatch repair (MMR), nucleotide excision repair (NER), base excision repair (BER) and recombinational repair [193]. Cd(II) was reported to affect the first three [180, 194, 195]. The relevance of DNA repair inhibition in carcinogenesis due to a chronic exposure to cadmium is supported by very low, non-cytotoxic Cd(II) levels, at which DNA repair inhibition is observed. There is sufficient evidence to assume that $\mathrm{Cd}(\mathrm{II})$ ions interfere with repair systems on the level of individual proteins involved, rather than at a DNA lesion site.

With respect to BER, Cd(II) inhibited repair of DNA oxidative damage products [196, 197]. The mechanism of this activity includes inhibition of several BER proteins, such as OGG1, which repairs 8-oxoguanine lesions [198] or PARP, which orchestrates single strand break repair [199]. The action on OGG1 appears to be indirect, via Sp1 transcription factor, while that on PARP may be direct. Cd(II) ions inhibit the first step of the NER system, the incision of the DNA lesion. Therefore, the XPA protein, a NER repair complex initiator was proposed to be the prime cadmium toxicity target [200]. The MMR inhibition by Cd(II) also involves a direct interaction with the repair complex, resulting in the decrease of ATP consumption by MSH6 protein, observed in human cell cultures [201, 202].

The above data for NER and BER are consistent with a concept of zinc fingers in DNA repair proteins as targets for carcinogenic $\mathrm{Cd}(\mathrm{II})$ ions, as many of the toxic effects described above could be reversed by an administration of $\mathrm{Zn}(\mathrm{II})$ ions. Chapter 4.3 presents molecular evidence for this idea in more detail. Zn(II) administration did not, however, reverse the inhibition of MHS6 exerted by Cd(II) ions, suggesting that the MMR pathway of cadmium toxicology involves oxygen, rather than sulfur binding sites. 


\subsubsection{Effects of $\mathrm{Cd}(\mathrm{II})$ on cellular junctions}

While cadmium primarily damages kidney, the metal is also known to readily assault vascular endothelium [203]. The focal point of cadmium toxicity towards these two targets is the interaction of the $\mathrm{Cd}(\mathrm{II})$ ions with cell adhesion molecules, which form cell-cell or cellmatrix junctions. In this respect, the most important junctions include adhering junctions and tight junctions (zonulae occludens) [204].

Adhering junction is a complex of transmembrane proteins - cadherins, whose intracellular domains form links with catenin scaffolding proteins, which, in turn, are physically linked with cellular skeleton proteins. Cadherins are single-span transmembrane proteins, responsible for calcium-dependent cell-cell adhesion. They can transfer information intracellularly through $\alpha$ - and $\beta$-catenins and actin skeleton [205]. $\beta$-catenin has a double function, it is both a structural protein and a transcription factor. It participates in the Wnt signalling pathway (controlling embryogenesis and involved in human carcinogenesis) via TCF/LEF proteins $[205,206]$. $\beta$-catenin trans-activates genes stimulating cell proliferation (like $c-m y c$ ) and also genes protecting from apoptosis (e.g. Abcbl) [206] and therefore may be involved in the malignant transformation.

Tight junctions comprise occludins, claudines, JAMs (junctional adhesion molecules) and ZO (zonula occludens proteins) proteins. They form a complex serving as a semipermeable barrier to the paracellular transport of ions, solutes, water, and cells (e.g. leukocytes). Tight junctions provide a barrier dividing the apical domains of plasma membranes from their basolateral parts [207].

It has been reported that in vascular and kidney epithelium cadmium disrupts the cadherin dependent cell-junctions. It is believed that $\mathrm{Cd}(\mathrm{II})$ binds at the $\mathrm{Ca}$ (II) binding domain, thereby disorganising the whole adhering junction complex. The molecular details of 
this instance of calcium/cadmium antagonism are not known. This action has a twofold effect: not only the cellular attachment loosens, but also the $\beta$-catenin molecule translocates to the nucleus where it exerts its gene-regulatory properties [204, 206]. In kidney, the disruption of cellular junctions takes place both in the proximal tubule and in vasculature [204]. It has been also reported that expression of the endothelium specific claudin-5 in tight junctions was irregular and diminished in the glomeruli and small blood vessels of the kidneys from Cdtreated rats [204]. Therefore, Cd(II) clearly influences at least two types of cell-cell junctions.

Due to its junction disrupting properties, cadmium exerts a direct antiangiogenic effect on vascular epithelium by redistributing vascular E-cadherin (VE-cadherin) from cell-cell contacts and disabling the migration and tube formation of endothelial cells [208]. This fact leads to the suggestion that under certain conditions, cadmium may have an anticarcinogenic effect by preventing formation of blood vessels feeding the growing tumor [203, 208].

Cadmium toxicity to other organs may also be attributed to the cadmium capacity to disrupt cell-cell junctions in the vascular endothelium. For example, in lungs the earliest stages of Cd-induced pulmonary injury involve the disruption of the alveolar septum and the leakage of fluid and solutes into the alveoli. This observation is in accordance with the fact that cadmium, via disruption of cellular junctions, increases the endothelial permeability [203].

\subsection{Molecular Mechanisms of Nickel Toxicity}

The studies of molecular mechanisms in nickel toxicology are virtually limited to two major nickel-dependent pathologies: allergy and carcinogenesis. Current views on these mechanisms are presented in respective sections below.

\subsubsection{Molecular mechanisms in nickel allergy}


Nickel allergy is a T-cell controlled disease [209]. The allergic reaction is a result of skin surface penetration by nickel, which results in the induction of cellular immune response. In this chapter we focus on those molecular events of nickel allergy that involve $\mathrm{Ni}(\mathrm{II})$ ions directly. Other important molecular aspects of immune system response to nickel exposure have been reviewed recently [210, 211].

The allergenic potential of a nickel containing material depends on its ability to deliver $\mathrm{Ni}(\mathrm{II})$ ions. The oxidation of metallic nickel to Ni(II) occurs in human sweat with a sufficient rate to elicit allergic reaction, while $\mathrm{NiO}$ particles, which do not dissolve in sweat, are not allergenic $[130,131,212]$. The translocation of nickel through the outer layers of skin occurs in the form of $\mathrm{Ni}(\mathrm{II})$ ions, most likely bound to proteins. Human serum albumin (HSA) is considered as a likely main $\mathrm{Ni}(\mathrm{II})$ shuttle, due to its high abundance and mobility in skin [213]. This protein contains a specific Ni(II) binding site at its Asp-Ala-His- N-terminal sequence [214-216]. Recently, another skin protein, filaggrin (FLG), has been implicated in $\mathrm{Ni}$ (II) binding in the skin. This large protein is necessary for the process of skin cornification, which provides a barrier preventing epidermal water loss and penetration by infectious agents, toxins and allergens [217]. A decrease of expression or loss-of-function mutations in FLG gene are seen in a large proportion of atopic dermatitis individuals, including those suffering from nickel allergy. In addition to a general barrier function, FLG is considered to provide $\mathrm{Ni}(\mathrm{II})$-specific defense by chelating $\mathrm{Ni}(\mathrm{II})$ ions [218, 219]. A role of recently discovered FLG2 in nickel allergy remains to be investigated [220].

Upon skin penetration, $\mathrm{Ni}(\mathrm{II})$ ions induce hyperreactivity by activating Human Leucocyte Antigen (HLA)-restricted, nickel-specific T cells. There is evidence for two concurrent mechanisms of initiation of immune response by Ni(II) [221]. Some T cells can react to HLA-associated peptidic determinants which include bound $\mathrm{Ni}$ (II). This mechanism is similar to the standard presentation of organic haptens, except for the fact that $\mathrm{Ni}$ (II) ions 
do not form strong, covalent bonds with presenting peptides. Instead, much more labile coordination bonds are formed. Another mechanism requires a permanent presence of surplus $\mathrm{Ni}(\mathrm{II})$ in the medium for activation, independent of peptides presented. These cells seem to be activated by $\mathrm{Ni}(\mathrm{II})$ complexation at TCR-MHC (T cell receptor-major histocompatibility complex) contact sites, which add strength to the TCR-MHC binding. HSA is a likely, but confirmed only in vitro, donor of $\mathrm{Ni}(\mathrm{II})$ to such complexes [213, 221]. Histidine residues in surface peptides have been implicated in $\mathrm{Ni}(\mathrm{II})$ binding in these more or less putative complexes [221-223].

Despite these developments, the chemical nature of $\mathrm{Ni}$ (II) interactions with $\mathrm{T}$ cells remains largely unknown. The allergic cross-reactivity between $\mathrm{Ni}(\mathrm{II})$ and $\mathrm{Pd}(\mathrm{II})$ has been noted $[224,225]$. This fact suggests that active Ni(II) complexes are square-planar, rather than octahedral, because Pd(II) complexes are always square-planar [10]. Very recently, it was demonstrated that $\mathrm{NiSO}_{4}$ triggers monocyte activation in a way that includes changes of cell surface thiols [226]. A hypothetical Ni(II)-thiol complex would also be square-planar [227]. Furthermore, experiments in mice suggested that Ni(II) compounds can activate T cells, but are unable to prime the naïve ones. The latter effect could be obtained by using preformed $\mathrm{Ni}(\mathrm{III})$ or $\mathrm{Ni}(\mathrm{IV})$ peptide complexes or by co-administration of $\mathrm{Ni}(\mathrm{II})$ with $\mathrm{H}_{2} \mathrm{O}_{2}$ [228, 229]. All these pieces of evidence point at the involvement of redox active planar $\mathrm{Ni}(\mathrm{II})$ species in the mechanism of nickel allergy $[177,230]$.

The ability of some metal ions to hydrolyze peptides was mentioned as potentially contributing to abnormal antigen processing, and thereby eliciting allergic response. However, no data were presented in support of this idea [231]. In this context, it is very interesting to note that $\mathrm{Ni}$ (II) ions are able to hydrolyze specific His-containing sequences, in vitro as well as intracellularly, yielding redox-active square-planar $\mathrm{Ni(II)}$ complexes [232-235]. Another interesting line of research stems from the epidemiological observation that a prolonged 
childhood contact with nickel-releasing orthodontic braces prior to ear piercing decreases incidence of nickel allergy. Reversing this order of events, however, provides no protection [236, 237]. Once sensitized, a patient can develop skin symptoms upon oral challenge with $\mathrm{Ni}(\mathrm{II})$ compounds [238]. The dose-dependent development of oral tolerance to $\mathrm{Ni}(\mathrm{II})$ was confirmed recently in an animal study, which showed that only mice challenged with $\mathrm{NiCl}_{2}$ orally had specific $\mathrm{Ni}(\mathrm{II})$ reactive regulatory $\mathrm{T}$ cells [239]. These data suggest the presence of specific chelation of $\mathrm{Ni}(\mathrm{II})$ somewhere in the digestive tract that results in a "safe" presentation of $\mathrm{Ni}(\mathrm{II})$ to the immune system. One can clearly state that despite significant progress, very much remains to be discovered with respect to molecular mechanisms in early stages of nickel allergy. Such knowledge is prerequisite for the development of nickel allergy medication.

\subsubsection{Molecular mechanisms in nickel carcinogenesis}

As presented above, nickel carcinogenicity depends on the water solubility of its compound. Insoluble, particulate $\mathrm{Ni}$ (II) compounds are stronger carcinogens than soluble compounds in both epidemiological and experimental animal studies. However, there is abundant evidence that soluble $\mathrm{Ni}(\mathrm{II})$ is the actual ultimate carcinogen for both types of compounds (for review, see $[54,133,177,240]$ ). The difference in health hazards is primarily due to the resistance of insoluble compounds to clearance from the site of exposure in the body. For example, $\mathrm{NiO}$ yields nickel lung burdens with persistence up to 1000 -fold higher than $\mathrm{NiSO}_{4}$ [241]. Furthermore particles of $\mathrm{Ni}(\mathrm{II})$ compounds of dimensions smaller than 5 $\mu \mathrm{m}$ can cross the cell membrane by phagocytosis, delivering very high amounts of nickel in the vicinity of cell nucleus [242-244]. The toxicity of nickel delivered this way depends on the efficiency of mobilization of $\mathrm{Ni}(\mathrm{II})$ ions by dissolution in lysosomes [243, 245, 246]. A very recent study demonstrated higher toxicity of $\mathrm{NiO}$ nanoparticles, compared to both fine (micrometer size) $\mathrm{NiO}$ particles and soluble $\mathrm{NiCl}_{2}$ in cell lines [247]. This property can be 
assigned to a combination of efficient particle delivery with fast intramolecular dissolution of small particles. By the way, this finding is the early sign of an emerging problem of nanoparticle toxicity.

Another, much slower way of delivering Ni(II) intracellularly is through DMT-1, which exhibits a broad metal ion specificity, and participates in Cd(II) transport as well [36, 248, 249]. This transport mode yields substantial amounts of cytosolic Ni(II), but particulate $\mathrm{Ni}(\mathrm{II})$ compounds, dissolved intracellularly were found to deliver a higher proportion of $\mathrm{Ni}(\mathrm{II})$ into the cell nucleus $[243,245]$. A non-specific diffusion through the cell membrane was also proposed [250]. The latter mechanism, however, seems to be less likely in vivo, except for the digestive tract.

Many molecular mechanisms were proposed for Ni(II) carcinogenesis, and the relative importance of these mechanisms is far from being understood. $\mathrm{Ni}$ (II) has been considered to be a source of reactive oxygen species (ROS) in the cell nucleus, with concomitant procarcinogenic DNA damage $[177,251]$. Indeed, the pattern of DNA damage in cells exposed to $\mathrm{Ni}(\mathrm{II})$ resembles that of ionizing radiation, which suggests the involvement of Ni(II)-generated ROS [252]. Even more importantly, G->T transversions, mutations typical for oxidative damage, were found in both experimental renal tumors induced by $\mathrm{Ni}_{3} \mathrm{~S}_{2}$, and in human lung cancers associated with nickel exposure [253, 254]. However, the mutagenicity of $\mathrm{Ni}$ (II) compounds is very low in many experimental systems, at odds with their high ability to induce neoplastic transformation [240, 255]. Several concepts were raised to overcome this apparent discrepancy. Cell line studies provided more or less stringent evidence for epigenetic mechanisms of nickel carcinogenesis. A unifying epigenetic concept has been proposed recently, which combines several hitherto separate molecular tracks [240]. $\mathrm{Ni}$ (II) exposure leads to alterations of acetylation, methylation and ubiquitylation of core histones, which may be associated with silencing of tumor suppressor and other cell cycle control genes [256-261]. 
$\mathrm{Ni}(\mathrm{II})$ ions are also able to damage histone $\mathrm{H} 2 \mathrm{~A}$ directly, by hydrolytic truncation of the Cterminal H2A octapeptide [234]. The presence of such truncated H2A in cultured cells resulted in an altered pattern of expression of cancer-related genes [262].

$\mathrm{Ni}$ (II) ions disturb intracellular redox control by depleting cellular stores of glutathione and ascorbate [263-267]. The latter event leads to the accumulation of Fe(III) in the cells. Finally, Ni(II)-exposed cells suffer from hypoxia, which is common to fast-growing tumors [268, 269]. The latter state facilitates selection of neoplastic phenotype that can escape apoptosis. This preconditioning may be combined with a weak, but present mutagenic ability of $\mathrm{Ni}(\mathrm{II})$ to complete carcinogenic transformation [240].

An order of these events may also be different for specific carcinogens. For example, $\mathrm{Ni}_{3} \mathrm{~S}_{2}$ dissolution is biphasic. The first, rapid phase is associated with high redox activity and may lead to the DNA damage, while the second, slow phase of $\mathrm{Ni}$ (II) release may elicit epigenetic damage [270].

The above phenomena result from exposures of cells to high levels of intracellular $\mathrm{Ni}(\mathrm{II})$, most likely to be induced by phagocytosis of nickel sulfides or oxide. However, low, non-cytotoxic Ni(II) levels may also cause DNA damage and neoplastic transformation. At low concentrations, $\mathrm{Ni}(\mathrm{II})$ ions strongly enhance mutagenicity of other carcinogens, by inhibiting DNA repair [193]. Such synergy of Ni(II) with mutagenic carcinogens, including UV irradiation, N-methyl-N-nitrosourea and benzo[a]pyrene was demonstrated in cell line experiments [271-273]. Ni(II) was demonstrated to inhibit the XPA protein, which enables the formation of the NER complex [274]. This cocarcinogenic mechanism can also very well explain the discrepancy between the low mutagenicity and the high carcinogenicity of $\mathrm{Ni}(\mathrm{II})$ compounds.

It seems that exposure to $\mathrm{Ni}(\mathrm{II})$ can induce many concurrent intracellular processes. Their relative relevance is likely do depend strongly on the type of tissue and cells affected. 
This general notion was formulated previously in the context of various strains of mice [270]. It is also valid on the most elementary molecular level. For example, the ability of $\mathrm{Ni}(\mathrm{II})$ to deplete GSH depended strongly on the cell line type [263-266]. Also, the efficiency of the direct attack of $\mathrm{Ni}(\mathrm{II})$ on histone $\mathrm{H} 2 \mathrm{~A}$ was cell type-specific [234]. To elucidate these and other basic mechanisms of $\mathrm{Ni}(\mathrm{II})$ interactions inside the cell one needs to find out about molecular forms of its presence. Taking into account the intracellular abundance of potential low and high molecular weight ligands for Ni(II), which can be estimated as higher than 20

$\mathrm{mM}$, hypothetical free $\mathrm{Ni}^{2+}$ aqua ions may only exist temporarily at the moment of dissolution of a particle. Studies using molecular models, aided by species distribution calculations suggest that essential metabolites, ATP and histidine, as well as histones may bind the majority of $\mathrm{Ni}(\mathrm{II})$ ions in the cell nucleus [232, 233, 275-278]. These data indicate another direction of future research, linking basic metabolism of particular cell types with their susceptibility to $\mathrm{Ni}(\mathrm{II})$-induced carcinogenesis. A clear protective effect of $\mathrm{Mg}$ (II) ions and other essential divalent metals against $\mathrm{Ni}_{3} \mathrm{~S}_{2}$ carcinogenesis seems to fall into the same category $[133,279]$.

\subsection{Interactions with zinc fingers - a common target for cadmium and nickel.}

Zinc finger $(\mathrm{ZF})$ domains are one of the most abundant families of protein motifs in the eukaryotic genome, comprising at least 3\% of identified human proteins [280]. Their functions include the binding and recognition of nucleic acids and formation of multiprotein complexes [281, 282]. Typical ZF domains contain one or two Zn(II) ions bonded tetrahedrally in $\mathrm{Cys}_{2} \mathrm{His}_{2}$, $\mathrm{Cys}_{3} \mathrm{His}$ or $\mathrm{Cys}_{4}$ environments, and ZF proteins contain from one to more than 20 individual ZF units [283]. Zn(II) does not participate in interactions of ZF, but secures their structure, so that zinc release results in the loss of the ZF function [284]. ZF are targets for oxidizing agents, and cellular toxicity of reactive oxygen and nitrogen species is attributed in part to oxidation of zinc-binding thiol groups in ZF [284, 285]. ZF were also 
proposed to be targeted by toxic metals, including $\mathrm{Ni}(\mathrm{II})$ and $\mathrm{Cd}(\mathrm{II})$. This issue is particularly interesting, because it provides a unifying mechanistic concept for carcinogenesis related to DNA repair inhibition [286]. Indeed, several DNA repair proteins, which are susceptible to inhibition by carcinogenic metals, contain zinc finger domains $[194,286]$. ZF is a dual target for a toxic metal ion, because its function can be compromised by metal-metal substitution as well as by metal-catalyzed oxidation of zinc binding thiols. Ni(II) ions form weaker complexes with all kinds of ZF than Zn(II) ions [227, 287-289]. Nevertheless, they were demonstrated to substitute for $\mathrm{Zn}(\mathrm{II})$ in $\mathrm{Cys}_{4}$ and $\mathrm{Cys}_{2} \mathrm{His}_{2} \mathrm{ZF}$ at a sufficient molar excess $[227,290]$. This substitution results in an alteration of ZF structure, because of the nontetrahedral geometry of the binding site, imposed by the $\mathrm{Ni}(\mathrm{II})$ ion $[227,287,288]$. Moreover, $\mathrm{Ni}(\mathrm{II})$ ions were shown to facilitate disulfide bridge formation and zinc release from XPAzf, a ZF peptide derived from the XPA DNA repair protein [227]. The relative affinity of Cd(II) ions to $\mathrm{ZF}$ vs. $\mathrm{Zn}$ (II) ions increases with the number of Cys residues in the $\mathrm{ZF}$ binding site [291]. It is lower for $\mathrm{Cys}_{2} \mathrm{His}_{2} \mathrm{ZF}$ [289-293]. On the other hand, Cys 4 ZF preferentially bind Cd(II) ions [287, 294]. The binding in the latter ZF is nearly isostructural, as demonstrated for XPAzf [295, 296]. Oppositely to the Ni(II) finger, Cd(II)-substituted XPAzf was much more resistant to oxidation than the parent $\mathrm{Zn}$ (II) complex [294]. These facts suggest that the ZFbased mechanisms of nickel and cadmium toxicity may be different. Ni(II) ions can assault ZF domains directly, or indirectly by eliciting oxidative damage. Cd(II) ions can impair physiological redox control of ZF activity, by protecting it when inhibition would be desired, e.g. in gene transcription regulation [284].

The yet unsolved issue of the molecular mechanism of $\mathrm{Cd}(\mathrm{II})$ xenoestrogenicity is also related to $\mathrm{ZF}$ interactions. The estrogen-mimicking activity of $\mathrm{Cd}(\mathrm{II})$ ions, mentioned in Chapter 3.1.2, appears to be largely due to their direct interaction with the the $\alpha$-subtype of estrogen receptor (ER $\alpha)$. Its DNA binding domain (DBD) and ligand binding domain (LBD) 
are two potential binding sites for $\mathrm{Cd}(\mathrm{II})$. DBD is a dimeric ZF structure, and its apo-form was demonstrated to reconstitute in the presence of $\mathrm{Cd}(\mathrm{II})$ ions. The resulting complex retained DNA binding properties of the native domain [297]. However, a $\mathrm{Zn}(\mathrm{II}) / \mathrm{Cd}(\mathrm{II})$ competition was not studied. LBD contains four Cys residues which were not seen to form disulfide bonds in crystal structures [298]. The issue of Cd(II) binding to these cysteines remains however, to be elucidated [299-301]. Notably, the $\mathrm{Zn}(\mathrm{II})$ ions were found not to bind to LBD, but the Ni(II) ions were found to do so with a high affinity [299].

\section{SUMMARY}

Toxic properties of cadmium and nickel are usually discussed separately, due to their obvious differences in chemical properties (such as ionic radii), preferred geometries of complexes with bioligands, and redox properties. However, the awareness of health hazards related to exposure to their compounds appears to be generally low. Therefore, we chose to describe these two elements together, in one chapter. Nevertheless, as described above, cadmium and nickel share some toxicologically relevant features. They are increasingly present in the human environment due to their joint technological usage, such as Ni-Cd batteries. They are co-emitted in fly ash generated in coal power plants and municipal waste incinerators and are simultaneously present in the tobacco smoke. As a result, they share the respiratory route of human exposure. The main difference between exposures to cadmium and nickel is due to the different levels at which toxic effects are induced. The lower presence of cadmium in the Earth crust corresponds to its higher toxicity, compared to nickel.

Further similarities between cadmium and nickel can be noticed in their fate in the human body. Both $\mathrm{Cd}(\mathrm{II})$ and $\mathrm{Ni}(\mathrm{II})$ ions are taken up in the digestive tract via divalent metal transporter (DMT-1), distributed in the blood by albumin and finally delivered to liver. A crucial difference in toxic properties between $\mathrm{Cd}(\mathrm{II})$ and $\mathrm{Ni}(\mathrm{II})$ ions results from the ability of 
$\mathrm{Cd}(\mathrm{II})$ (and inability of $\mathrm{Ni}(\mathrm{II})$ ) to induce metallothionein synthesis in hepatocytes. This difference is probably due to the distinct geometric requirements of thiolate complexes: $\mathrm{Cd}(\mathrm{II})$ eagerly forms a tetrahedral structure, while $\mathrm{Ni}$ (II) strongly prefers a square-planar geometry of the complex. The long term accumulation of cadmium within the human body and cadmium nephrotoxicity appear to be the distant consequence of this difference in its geometric requirements. In contrast, some data, reviewed above, seem to indicate that the preference of $\mathrm{Ni}(\mathrm{II})$ to form planar complexes containing sulfur atoms may be partially responsible for the nickel allergy. Despite these differences, both $\mathrm{Cd}(\mathrm{II})$ and $\mathrm{Ni}(\mathrm{II})$ were shown to deplete intracellular glutathione and elicit oxidative stress, which is likely relevant in their carcinogenesis.

DNA repair inhibition is a yet another common area of cadmium and nickel toxicity. Subcellular and molecular studies indicate that both these metals may actually target the same zinc finger (ZF) domains in repair complex components. However, specific mechanisms of this interference differ on the molecular level, as Ni(II) destroys ZF structures, while Cd(II) appears to stabilize them, in comparison to the native $\mathrm{Zn}(\mathrm{II})$ ion.

The above presented data provide a reason for research on the effects of joint exposures to $\mathrm{Cd}(\mathrm{II})$ and $\mathrm{Ni}(\mathrm{II})$. The combination of analogies and discrepancies of their molecular properties, discussed briefly above, makes them potentially synergic toxins, properties of which need to be investigated in order to provide a better protection for humans exposed. 


\section{References}

1. P.W. Durbin and S. Lauriston, Taylor Lecture: the quest for therapeutic actinide chelators, Health Phys. 2008, 95, 465-492.

2. G.D. Howells, D.J.A. Brown and K. Sadler, Effects of acidity, calcium, and aluminum on fish survival and productivity - a review, J. Sci. Food Agric. 1983, 34, 559-570.

3. D.W. Schindler, Effects of acid rain on freshwater ecosystems, Science 1988, 239, 149-157.

4. L. Alessio, M. Campagna and R. Lucchini, From lead to manganese through mercury: mythology, science, and lessons for prevention, Am. J. Ind. Med. 2007, 50, 779-787.

5. J. Schwartz, Low-level lead exposure and children's IQ: a meta-analysis and search for a threshold, Environ 1994, 65, 42-55.

6. L. Magos and T.W. Clarkson, Overview of the clinical toxicity of mercury, Ann. Clin. Biochem. 2006, 43, 257-268.

7. D. Seyferth, The rise and fall of tetraethyllead. 2, Organometallics, 2003, 22, 5154-5178.

8. R.F. Edlich, C.L. Cross, C.A. Wack, W.B. Long $3^{\text {rd }}$ and A.T. Newkirk, The food and drug administration agrees to classify mercury fillings, J. Environ. Pathol. Toxicol. Oncol. 2008, 27, 303-305.

9. S. Trümpler, W. Lohmann, B. Meermann, W. Buscher, M. Sperling and U. Karst, Interaction of thimerosal with proteins - ethylmercury adduct formation of human serum albumin and $\beta$-lactoglobulin A, Metallomics 2009, 1, 87-91.

10. F.A. Cotton, G. Wilkinson, C.A. Murillo and M. Bochmann, Advanced Inorganic Chemistry, 6. Ed., 1999, Wiley, New York.

11. A. Frenkel, A. Vairavamurthy and M. Newville, A study of the coordination environment in aqueous cadmium-thiol complexes by EXAFS spectroscopy: experimental vs theoretical standards, J. Synchrotron Rad. 2001, 8, 669-671.

12. R.G. Pearson, Hard and soft acids and bases, J. Am. Chem. Soc. 1963, 85, 3533-3539.

13. B.A. Krizek, D.L. Merkle and J.M. Berg, Ligand variation and metal ion binding specificity in zinc finger peptide, Inorg. Chem. 1993, 32, 937-940.

14. S.B. Mulrooney and R.P. Hausinger, Nickel uptake and utilization by microorganisms. FEMS Microbiol. Rev. 2003, 27, 239-261.

15. D.W. Margerum and S.L. Anliker, Nickel(III) Chemistry and Properties of the Peptide Complexes of $\mathrm{Ni}(\mathrm{II})$ and $\mathrm{Ni}(\mathrm{III})$, in Bioinorganic Chemistry of Nickel, ed. J.R. Lancaster, Jr., VCH Publishers, Weinheim, New York, 1988, pp. 29-51.

16. W. Bal, M.I. Djuran, D.W. Margerum, E.T. Gray, Jr., M. A. Mazid, R. T. Tom, E. Nieboer and P.J. Sadler, Dioxygen-induced decarboxylation and hydroxylation of [Ni ${ }^{\text {II }}$ Glycyl-Glycyl-L-Histidine)] occurs via $\mathrm{Ni}^{\mathrm{III}}$ : X-ray crystal structure of 
[Ni ${ }^{\mathrm{II}}$ (Glycyl-Glycyl- $\alpha$-hydroxy-D,L-Histamine) $] 3 \mathrm{H}_{2} \mathrm{O}$, J. Chem. Soc., Chem. Comm. 1994, 1889-1890.

17. C.L. Coyle and E.I. Stiefel, The coordination chemistry of nickel: an introductory survey. in Bioinorganic Chemistry of Nickel, ed. J.R. Lancaster, Jr., VCH Publishers, Weinheim, New York, 1988, pp. 1-28.

18. Mindat.org - the mineral and locality database, http://www.mindat.org/min-3040.html

19. B.R. Singh and M.J. McLaughlin, Cadmium in soils and plants, in Developments in Plant and Soil Sciences, M.J. McLaughlin and B.R. Singh, eds., Kluwer Academic Publishers, Dordrecht 1999, pp. 257-268.

20. T.W. Lane and F.M.M. Morel, A biological function for cadmium in marine diatoms, Proc. Natl. Acad. Sci. 2000, 97, 4627-4631.

21. F.M.M. Morel, The co-evolution of phytoplankton and trace element cycles in the oceans, Geobiology 2008, 6, 318-324.

22. J. Wang, H. Ban, X. Teng, H. Wang and K. Ladwig, Chemosphere 2006, 64, 1892-1898.

23. A. Baba and A. Kaya, Leaching characteristics of solid wastes from thermal power plantsof western Turkey and comparison of toxicity methodologies, J. Environ. Manage. 2004, 73, 199-207.

24. M. Takaoka, Y. Kuramoto, N. Takeda and T. Fujiwara, Estimation of species of zinc, lead, copper and cadmium in fly ash by a sequencial chemical extraction method, Proc. JSCE 2001, 685, 79-90.

25. M.C. Camerani, A. Somogyi, B. Vekemans, S. Ansell, A.S. Simionovici, B.M. Steenari and I. Panas, Determination of the Cd-bearing phases in municipal solid waste and biomass single fly ash particles using SR-microXRF spectroscopy, Anal. Chem. 2007, 79, 6496-6506.

26. M.C. Camerani Pinzani, S. Ansell, A. Somogyi, B.M. Steenari and O. Lindqvist, Microextended X-ray absorption fine structure studies of cadmium speciation within single municipal solid waste fly ash particles, Anal. Chem. 2004, 76, 1596-1602.

27. M.C. Pinzani, A. Somogyi, A.S. Simionovici, S. Ansell, B.M. Steenari and O. Lindqvist, Direct determination of cadmium speciation in municipal solid waste fly ashes by synchrotron radiation induced mu-X-ray fluorescence and mu-X-ray absorption spectroscopy, Environ. Sci. Technol. 2002, 36, 3165-3169.

28. C.H. Williams and D.J. David, The effect of superphosphate on the cadmium content of soils and plants. Austral. J. Soil Res. 1973, 11, 43-56.

29. A. Zaniewicz-Bajkowska, R. Rosa, J. Franczuk and E. Kosterna, Direct and secondary effect of liming and organic fertilization on cadmium content in soil and in vegetables, Plant Soil Environ. 2007, 53, 473-481. 
30. K. Rustemeier, R. Stabbert, H.J. Haussmann, E. Roemer and E.L. Carmines, Evaluation of the potential effects of ingredients added to cigarettes. Part 2: chemical composition of mainstream smoke. Food Chem. Toxicol. 2002, 40, 93-104.

31. A. Mutti, M. Corradi, M. Goldoni, M.V. Vettori, A. Bernard and P. Apostoli, Exhaled metallic elements and serum pneumoproteins in asymptomatic smokers and patients with COPD or asthma, Chest 2006, 129, 1288-1297.

32. K.S. Min, N. Iwata, N. Tetsutikawahara, S. Onosaka and K. Tanaka. Effect of hemolytic and iron-deficiency anemia on intestinal absorption and tissue accumulation of cadmium, Toxicol. Lett. 2008, 179, 48-52.

33. L. Nasreddine and D. Parent-Massin, Food contamination by metals and pesticides in the European Union. Should we worry? Toxicol. Lett. 2002, 127, 29-41.

34. P.G. Reeves and R.L. Chaney, Bioavailability as an issue in risk assessment and management of food cadmium: A review, Sci. Total Environ. 2008, 398, 13-19.

35. M. Vahter, M. Berglund, B. Nermell and A. Åkesson, Bioavailability of cadmium from shellfish and mixed diet in women. Toxicol. Appl. Pharmacol. 1996, 136, 332-341.

36. T. Suzuki, K. Momoi, M. Hosoyamada, M. Kimura and T. Shibasaki, Normal cadmium uptake in microcytic anemia $\mathrm{mk} / \mathrm{mk}$ mice suggests that DMT1 is not the only cadmium transporter in vivo, Toxicol. Appl. Pharmacol. 2008, 227, 462-427.

37. ATSDR, Cadmium toxicity - case studies in environmental medicine. Agency for Toxic Substances and Disease Registry, U.S. Department of Health and Human Services, Atlanta, GA, 2008.

38. Y. Suwazono, T. Kido, H. Nakagawa, M. Nishijo, R. Honda, E. Kobayashi, M. Dochi and K. Nogawa, Biological half-life of cadmium in the urine of inhabitants after cessation of cadmium exposure, Biomarkers, 2009, 14, 77-81.

39. M.P. Waalkes, Cadmium carcinogenesis, Mutat. Res. 2003, 533, 107-120.

40. M. Trzcinka-Ochocka, M. Jakubowski, G. Razniewska, T. Halatek and A. Gazewski, The effects of environmental cadmium exposure on kidney function: the possible influence of age. Environ. Res. 2004, 95, 143-150.

41. SARA Group. Sudbury soils study. Metals health environment. www.sudburysoilsstudy.com

42. D.L. Eskew, R.M. Welch and E.E. Cary, Nickel: an essential micronutrient for legumes and possibly all higher plants, Science 1983, 222, 621-623.

43. A. Sirko and R. Brodzik, Plant ureases: Roles and regulation, Acta Biochim. Polon. 2000, 47, 1189-1195.

44. F.H. Nielson. Nickel, in, Trace elements inhuman and animal nutrition, vol. 1, ed. W. Mertz, 5th ed., Academic Press, San Diego, 1987, pp. 245-273. 
45. F.W. Sunderman Jr., S.M. Hopfer and K.R. Sweeney, Nickel absorption and kinetics in human volunteers, Proc. Soc. Exp. Biol. Med. 1989, 191, 5-11.

46. S.E. Horak and F.W. Sunderman Jr., Fecal nickel excretion by healthy adults, Clin. Chem. 1972, 19, 429-430.

47. D.R. Myron, T.J. Zimmermann and T.R. Shuler, Intake of nickel and vanadium by humans, Am. J. Clin. Nutr. 1978, 31, 527-531.

48. A. Tossavainen, M. Nurminen, P. Mutanen and S. Tola, Application of mathematical modelling for assessing the biological halftimes of chromium and nickel in field studies, Br. J. Ind. Med. 1980, 37, 285-291.

49. M. Anke, L. Angelow, M. Glei, M. Müller and H. Illing, The biological importance of nickel in the food chain, Fresenius J. Anal. Chem. 1995, 352, 92-96.

50. F.W. Sunderman Jr., R.M. Maenza, P.R. Alpass, J.M.Mitchell, I. Damjanov and P.J. Goldblatt, Carcinogenicity of nickel subsulfide in Fischer rats and Syrian hamsters after administration by various routes, Adv. Exp. Med. Biol. 1977, 91, 57-67.

51. W. Torjussen and I. Anderson, Nickel concentrations in nasal mucosa, plasma, and urine in active and retired nickel workers, Ann. Clin. Lab. Sci. 1979, 9, 289-298.

52. D.C. Muir, N. Jadon, J.A. Julian and R.S. Roberts, Cancer of the respiratory tract in nickel sinter plant workers: effect of removal from sinter plant exposure, Occup. Environ. Med. 1994, 51, 19-22.

53. KB Svenes and I. Andersen, Distribution of nickel in lungs from former nickel workers, Int. Arch. Occup. Environ. Health 1998, 71, 424-428.

54. E. Denkhaus and K. Salnikow, Nickel essentiality, toxicity, and carcinogenicity, Crit. Rev. Oncol. Hematol. 2002, 42, 35-56.

55. E.D. Segal, S.J. Shon, L.S. Tompkins, Characterization of Helicobacter pylori urease mutants. Infect. Immunol. 1992, 60, 1883-1889.

56.

57. K.C. Galbreath, R.L. Schulz, D.L. Toman, C.M. Nyberg, F.E. Huggins, G.P. Huffman and E.J. Zillioux, Nickel and sulfur speciation of residual oil fly ashes from two electric utility steam-generating units, J. Air Waste Manag. Assoc. 2005, 55, 309-318.

59. K. Brigden and D. Santillo, Heavy metal and metalloid content of fly ash collected from the Sual, Mauban and Masinloc coal-fired power plants in the Philippines, Greenpeace Research Laboratories Technical Note 7/2002, www.greenpeace.to/publications/philflyash.pdf

60. A. Profumo, G. Spini, L. Cucca and M. Pesavento, Determination of inorganic nickel compounds in the particulate matter of emissions and workplace air by selective sequential dissolutions, Talanta 2003, 61, 465-472. 
61. S. Pattanaik, F.E. Huggins, G.P. Huffman, W.P. Linak and C.A. Miller, XAFS studies of nickel and sulfur speciation in residual oil fly-ash particulate matters (ROFA PM).

Environ. Sci. Technol. 2007, 41, 1104-1110.

62. E. Soco and J. Kalembkiewicz, Investigations of chemical fraction of $\mathrm{Co}$ and $\mathrm{Ni}$ in industrial fly ash and mobility of metals in environmental conditions, Chemosphere 2007, 67, 359-364.

63. U.P. Kodavanti, R. Hauser, D.C. Christiani, Z.H. Meng, J. McGee, A. Ledbetter, J. Richards and D.L. Cost,. Pulmonary responses to oil fly ash particles in the rat differ by virtue of their specific soluble metals, Toxicol. Sci. 1998, 43, 204-212.

64. A.K. Prahalad, J.M. Soukup, J. Inmon, R. Willis, A.J. Ghio, S. Becker and J.E. Gallagher, Ambient air particles: effects on cellular oxidant radical generation in relation to particulate elemental chemistry, Toxicol. Appl. Pharmacol. 1999, 158, 81-91.

65. A.K. Prahalad, J. Inmon, A.J. Ghio and J.E. Gallagher, Enhancement of 2'deoxyguanosine hydroxylation and DNA damage by coal and oil fly ash in relation to particulate metal content and availability, Chem. Res. Toxicol. 2000, 13, 1011-1019.

66. D.L. Costa, J.R. Lehmann, D. Winsett, J. Richards, A.D. Ledbetter and K.L. Dreher, Comparative pulmonary toxicological assessment of oil combustion particles following inhalation or instillation exposure, Toxicol. Sci. 2006, 91 237-246.

67. M.E. Klein-Patel, G. Diamond, M. Boniotto, S. Saad and L.K. Ryan, Inhibition of betadefensin gene expression in airway epithelial cells by low doses of residual oil fly ash is mediated by vanadium, Toxicol. Sci. 2006, 92, 115-125.

68. A. Di Pietro, G. Visalli, F. Munaò, B. Baluce, S. La Maestra, P. Primerano, F. Corigliano and S. De Flora, Oxidative damage in human epithelial alveolar cells exposed in vitro to oil fly ash transition metals, Int. J. Hyg. Environ. Health 2009, 212, 196-208.

69. R.A. Goyer and M.G. Cherian, Renal effects of metals, in Metal Toxicology, eds. R.A. Goyer, C.D. Klaassen and M.D. Waalkes, Academic Press, San Diego, 1995, pp. 389412.

70. K. Iwata, H. Saito, M.. Moriyama and A. Nakano, Renal tubular function after reduction of environmental cadmium exposure: A ten-year follow-up, Arch. Environ. Health 1993, 48, 157-163.

71. Y. Ando, E. Shibata, F. Tsuchiyama and S. Sakai, Elevated urinary cadmium concentrations in a patient with acute cadmium pneumonitis, Scand. J. Work Environ. Health 1996, 22, 150-153.

72. T. Gordon, Respiratory System, in Metal Toxicology, eds. R.A. Goyer, C.D. Klaassen and M.D. Waalkes, Academic Press, San Diego, 1995, pp. 237-263.

73. J.A. Thomas, Gonadal-specific metal toxicology, in Metal Toxicology, eds. R.A. Goyer, C.D. Klaassen and M.D. Waalkes, Academic Press, San Diego, 1995, pp. 413-446.

74. IARC, Cadmium and certain cadmium compounds. In: World Health Organization, eds. IARC monographs on the evaluation the carcinogenic risk of chemicals to humans. 
Beryllium cadmium, mercury and exposures in the glass manufacturing industry. vol. 58, Lyon, International Agency for Research on Cancer, 1993, pp. 120-136.

75. M.C.Henson and P.J.Chedrese, Endocrine disruption by cadmium, a common environmental toxicant with paradoxical effects on reproduction. Exp. Biol. Med. 2004, 229, 383-392.

76. M.H. Bhattacharyya, E.K. Silbergeld, E. Jeffery, A.K. Wilson and L. Watson, Metalinduced osteotoxicities, in Metal Toxicology, eds. R.A. Goyer, C.D. Klaassen and M.D. Waalkes, Academic Press, San Diego, 1995, pp. 465-510.

77. G.F. Nordberg, Historical perspectives on cadmium toxicology, Toxicol. Appl. Pharmacol. 2009, 238, 192-200.

78. K. Arisawa, A. Nakano, H. Saito, X.-J. Liu, M. Yokoo, M. Soda, T. Koba, T. Takahashi and K. Kinoshita, Mortality and cancer incidence among a population previously exposed to environmental cadmium, Int. Arch. Occup. Environ. Health 2001, 74, $255-$ 262.

79. H.C. Gonick, Nephrotoxicity of cadmium and lead, Indian J. Med. Res. 2008, 128, 335352.

80. A. Bernard, A. Goret, H. Roels, J.P. Buchet and R. Lauwerys, Experimental confirmation in rats of the mixed type proteinuria observed in workers exposed to cadmium.

Toxicology 1978, 10, 369-375.

81. H. Roels, A. Bernard, J.P. Buchet, A. Goret, R. Lauwerys, D.R. Chettle, T.C. Harvey and I.A. Haddad, Critical concentration of cadmium in renal cortex and urine. Lancet 1979, 1(8109), 221.

82. A.M. Bernard and R.R. Lauwery, Dose-reponse relations between urinary cadmium and tubular proteinuria in adult workers. Am. J. Ind. Med. 1997, 31, 116-118.

83. S. Satarug and M.R.Moore, Adverse health effects of chronic exposure to low level cadmium in foodstuffs and cigarette smoke, Environ. Health Perspect. 2004, 112, 1099 1103.

84. K.J. Ellis, W.D. Morgan, I. Zanzi, S. Yasumura, D. Vartsky and S.H. Cohn, In vivo measurement of critical level of kidney cadmium: dose effect studies in cadmium smelter workers. Am. J. Ind. Med. 1980, 1, 339-348.

85. J.R. Edwards and W.C. Prozialeck, Cadmium, diabetes and chronic kidney disease, Toxicol. Appl. Pharmacol. 2009, 238, 289-293.

86. E.R. Siu, D.D. Mruk, C.S. Porto amd Y. Cheng, Cadmium-induced testicular injury, Toxicol. Appl. Pharmacol. 2009, 238, 240-249.

87. J. Thompson and J. Bannigan, Cadmium: toxic effects on the reproductive system and the embryo, Reprod. Toxicol. 2008, 25, 304-315.

88. M. Takiguchi and S. Yoshihara, New aspects of cadmium as endocrine disruptor, Environ. Sci. 2006, 13, 107-116. 
89. Y. Zang, S. Odwin-DaCosta and J.D. Yager, Effects of cadmium on estrogen receptor mediated signaling and estrogen induced DNA synthesis in T47D human breast cancer cells, Toxicol. Lett. 2009, 184, 134-138.

90. R.A. Pauwels, A.S. Buist, P.M. Calverley, C.R. Jenkins and S.S. Hurd, GOLD Scientific Committee. Global strategy for the diagnosis, management, and prevention of chronic obstructive pulmonary disease. NHLBI/WHO Global Initiative for Chronic Obstructive Lung Disease (GOLD) Workshop summary, Am. J. Respir. Crit. Care 2001, 163, 12561276.

91. A. Mutti, M. Corradi, M. Goldoni, M.V. Vettori, A. Bernard and P. Apostoli, Exhaled metallic elements and serum pneumoproteins in asymptomatic smokers and patients with COPD or asthma, Chest 2006, 129, 1288-1297.

92. S. Weinmann, W.M. Vollmer, V. Breen, M. Heumann, E. Hnizdo, J. Villnave, B. Doney, M. Graziani, M.A. McBurnie and A.S. Buist, COPD and occupational exposures: a case-control study, J. Occup. Environ. Med. 2008, 50, 561-569.

93. D.M. Mannino, F. Holguin, H.M. Greves, A. Savage-Brown, A.L. Stock and R.L. Jones, Urinary cadmium levels predict lower lung function in current and former smokers: data from the Third National Health and Nutrition Examination Survey, Thorax 2004, 59, 194-198.

94. B.J. Lampe, S.K. Park, T. Robins, B. Mukherjee, A.A. Litonjua, C. Amarasiriwardena, M. Weisskopf, D. Sparrow and H. Hu, Association between 24-hour urinary cadmium and pulmonary function among community-exposed men: the VA Normative Aging Study. Environ. Health Perspect. 2008, 116, 1226-1230.

95. http://www-cie.iarc.fr/monoeval/grlist.html

96. M.P. Waalkes, Cadmium carcinogenesis, Mutat. Res. 2003, 533, 107-120.

97. J. Huff, R.M. Lunn, M.P. Waalkes, L. Tomatis and P.F. Infante, Cadmium-induced cancers in animals and in humans, Int. J. Occup. Environ. Health 2007, 13, 202-212.

98. J. Siemiatycki, R. Dewar, L. Nadon and M. Gerin, Occupational risk factors for bladder cancer: Results from a case control study in Montreal, Quebec, Canada, Am. J. Epidemiol. 1994, 140, 1061-1080.

99. E. Kellen, M. Zeegers, E.D. Hond and F. Buntinx, Blood cadmium may be associated with bladder carcinogenesis; the Belgian case control study on bladder cancer, Cancer Detect. Prev. 2007, 31, 77-82.

100. C. Murta-Nascimento, B.J. Schmitz-Dräger, M.P. Zeegers, G. Steineck, M. Kogevinas, F.X. Real and N. Malats, Epidemiology of urinary bladder cancer: from tumor development to patient's death. World J. Urol. 2007, 25, 285-295.

101. C. Samanic, M. Kogevinas, M. Dosemeci, N. Malats, F.X. Real, M. Garcia-Closas, C. Serra, A. Carrato, R. García-Closas, M. Sala, J. Lloreta, A. Tardón, N. Rothman and D.T. Silverman, Smoking and bladder cancer in Spain: effects of tobacco type, timing, environmental tobacco smoke, and gender. Cancer Epidemiol. Biomarkers Prev. 2006, 15, 1348-1354. 
102. D.A. Sens, S. Park, V. Gurel, M.A. Sens, S.H. Garrett and S. Somji, Inorganic, camiumand arsenite-induced malignant transformation of human bladder urothelial cells.

Toxicol. Sci. 2004, 79, 56-63.

103. M.E. Parent and J. Siemiatycki, Occupation and prostate cancer, Epidemiol. Rev. 2001, 23, 138-143.

104. L. Terracio and M. Nachtigal, Oncogenicity of rat prostate cells transformed in vitro with cadmium chloride. Arch. Toxicol. 1988, 61, 450-456.

105. M.P. Waalkes and S. Rehm, Cadmium and prostate cancer, J. Toxicol. Environ. Health 1994, 43, 251-269.

106. W.E. Achanzar, B.A. Diwan, S.T. Quader, M.M. Webber and M.P. Waalkes, Cadmiuminduced malignant transformation of human prostate epithelial cells, Cancer Res. 2001, 61, 455-458.

107. J.-D. Lee, S.-M. Wu, L.-Y. Lu, Y.-T. Yang and S.-Y. Jeng, Cadmium concentration and metallothionein expression in prostate cancer and benign prostatic hyperplasia of humans, J. Formos. Med. Assoc. 2009, 108, 554-559

108. G.G. Schwartz and I.M. Reis, Is cadmium a cause of human pancreatic cancer? Cancer Epidemiol. Biomarkers Prev. 2000, 9, 139-145.

109. A.M. Kriegel, A.S. Soliman, Q. Zhang, N. El-Ghawalby, F. Ezzat, A. Soultan, M. AbdelWahab, O. Fathy, G. Ebidi, N. Bassiouni, S.R. Hamilton, J.L. Abbruzzese, M.R. Lacey and D.A. Blake, Serum Cadmium Levels in Pancreatic Cancer Patients from the East Nile Delta Region of Egypt, Environ. Health. Perspect. 2005, 113, 113-119.

110. American Cancer Society. 2005. Cancer Facts and Figures, 2005. Atlanta, GA, American Cancer Society. www.cancer.org/downloads/STT/CAFF2005f4PWSecured.pdf

111. B. Pesch, J. Haerting, U. Ranft, A. Klimpel, B. Oelschlagel and W. Schill, Occupational risk factors for renal cell carcinoma: agent-specific results from a case-control study in Germany. MURC Study Group. Multicenter urothelial and renal cancer study. Int. J. Epidemiol. 2000, 29, 1014-1024.

112. J. Hu, Y. Mao and K. White, Canadian Cancer Registries Epidemiology Research Group, Renal cell carcinoma and occupational exposure in Canada, Occup. Med. 2002, 52, 157164.

113. S. Pacini, T. Punzi, G. Morucci, M. Gulisano, M. Ruggiero, A paradox of cadmium: a carcinogen that impairs the capability of human breast cancer cells to induce angiogenesis, J. Environ. Pathol. Toxicol. Oncol. 2009, 28, 85-88.

114. C. Byrne, S.D. Divekar, G.B. Storchan, D.A. Parodi and M.B. Martin, Cadmium - a metallohormone? Toxicol. Appl. Pharmacol. 2009, 238, 266-271.

115. A. Akesson, B. Julin and A. Wolk, Long-term dietary cadmium intake and postmenopausal endometrial cancer incidence: a population-based prospective cohort study. Cancer Res. 2008, 68, 6435-6441. 
116. T. Shirakawa, Y. Kusaka, N. Fujimura, M. Kato, S. Heki and K. Morimoto, Hard metal asthma: cross immunological and respiratory reactivity between cobalt and nickel? Thorax 1990, 45, 267-271.

117. V.P. Chashschin, G.P. Artunina, T. Norseth, Congenital defects, abortion and other health effects in nickel refinery workers, Sci. Total Environ. 1994, 148, 287-291.

118. A. Vaktskjold, L.V. Talykova, V.P. Chashchin, J.Ø. Odland and E. Nieboer, Spontaneous abortions among nickel-exposed female refinery workers, Int. J. Environ. Health Res. 2008, 18, 99-115.

119. L. Mond, K. Langer and F. Quincke, Action of carbon monoxide on nickel, J. Chem. Soc. 1890, 57, 749-753.

120. F.W. Sunderman and J.F. Kincaid, Nickel poisoning: II. Studies on patients suffering from acute exposure to vapors of nickel carbonyl. JAMA 1954, 155, 889-894.

121. Z. Shi, Nickel carbonyl: toxicity and human health, Sci. Total Environ. 1994, 148, $293-$ 298.

122. F.W. Sunderman Jr., B. Dingle, S.M. Hopfer and T. Swift, Acute nickel toxicity in electroplating workers who accidently ingested a solution of nickel sulfate and nickel chloride, Am. J. Ind. Med. 1988, 14, 257-266.

123. H.A. Krob, A.B. Fleischer, Jr., R. D’Agostino, Jr, C.L. Haverstock and S Feldman, Prevalence and relevance of contact dermatitis allergens: a meta-analysis of 15 years of published T.R.U.E. test data. J. Am. Acad. Dermatol. 2004, 51, 349-353.

124. W. Uter, A. Pfahlberg, O. Gefeller, J. Geier J and A. Schnuch, Risk factors for contact allergy to nickel - results of a multifactorial analysis. Contact Dermatitis 2003, 48, 33 38 .

125. J.P. Thyssen, P. Jensen, J.D. Johansen and T. Menné, Contact dermatitis caused by nickel release from hair clasps purchased in a country covered by the EU Nickel Directive. Contact Dermatitis 2009, 60, 180-181.

126. COMMISSION DIRECTIVE 2004/96/EC of 27 September 2004 amending Council Directive 76/769/EEC as regards restrictions on the marketing and use of nickel for piercing post assemblies for the purpose of adapting its Annex I to technical progress. Official Journal of the European Union L 301/51, 28.9.2004.

127. S.E. Jacob, J.N. Moennich, B.A. McKean, M.J. Zirwas and J.S. Taylor, Nickel allergy in the United States: A public health issue in need of a "nickel directive", J. Am. Acad. Dermatol. 2009, 60, 1067-1069.

128. R.L. Rietschel, J.F. Fowler, E.M. Warshaw, D. Belsito, V.A. DeLeo, H.I. Maibach, J.G. Marks, C.G. Mathias, M. Pratt, D. Sasseville, F.J. Storrs, J.S. Taylor and K.A. Zug, Detection of nickel sensitivity has increased in North American patch-test patients, Dermatitis 2008, 19, 16-19.

129. S.E. Jacob, B. Brod and G.H. Crawford, Clinically relevant patch test reactions in children - a United States based study, Pediatr. Dermatol. 2008, 25, 520-527. 
130. F.O. Nestle, H. Speidel and M.O. Speidel, High nickel release from1- and 2-euro coins, Nature 2002, 419, 132.

131. C. Lidén, L. Skare and M. Vahter, Release of nickel from coins and deposition onto skin from coin handling - comparing euro coins and SEK, Contact Dermatitis 2008, 59, 3137.

132. International Agency for Research on Cancer, IARC Monographs on the Evaluation of Carcinogenic Risks to Humans, vol. 49, Chromium, Nickel and Welding, IARC Scientific Publications, Lyon, 1990, pp. 257-445.

133. K.S. Kasprzak, F. W. Sunderman Jr. and K. Salnikow, Nickel carcinogenesis, Mutat. Res. 2003, 533, 67-97.

134. E.W. Baader, Berufkrebs, Neu. Ergeb. Geb. Krebskrankh. 1937, 1, 104-128.

135. R. Doll, Cancer of the lung and nose in nickel workers, Br. J. Ind. Med. 1958, 15, $217-$ 223.

136. R. Doll, Report of the International Committee on Nickel Carcinogenesis in Man, Scand. J. Work. Environ. Health 1990, 16, 9-82.

137. T.K. Grimsrud, S.R. Berge, J.I. Martinsen and A. Andersen, Lung cancer incidence among Norwegian nickel-refinery workers, 1953-2000, J. Environ. Monit. 2003, 5, 190-197.

138. F.W. Sunderman Jr., L.G. Morgan, A. Andersen, D. Ashley and F.A. Forouhar, Histopathology of sinonasal and lung cancers in nickel refinery workers, Ann. Clin. Lab. Sci. 1989, 19, 44-50.

139. M. Lippmann, D.B. Yeates, R.E. Albert, Deposition, retention, and clearance of inhaled particles, Br. J. Ind. Med. 1980, 37, 337-362.

140. K.S. Kasprzak, P. Gabryel and K. Jarczewska, Carcinogenicity of nickel(II) hydroxides and nickel(II) sulfate in Wistar rats and its relation to the in vitro dissolution rates, Carcinogenesis 1983, 4, 275-279.

141. M. Shibata, K. Izumi, N. Sano, A. Akagi and H. Otsuka, Induction of soft tissue tumours in F344 rats by subcutaneous, intramuscular, intra-articular, and retroperitoneal injection of nickel sulphide $\left(\mathrm{Ni}_{3} \mathrm{~S}_{2}\right)$, J. Pathol. 1989, 157, 263-274.

142. G.D. Stoner, M.B. Shimkin, M.C. Troxell, T.L. Thompson and L.S. Terry, Test for carcinogenicity of metallic compounds by the pulmonary tumor response in strain A mice, Cancer Res. 1976, 36, 1744-1747.

143. K.S. Kasprzak, B.A. Diwan, N. Konishi, M. Misra and J.M. Rice, Initiation by nickel acetate and promotion by sodium barbital of renal cortical epithelial tumors in male F344 rats, Carcinogenesis 1990, 11, 647-652.

144. B.A. Diwan, K.S. Kasprzak and J.M. Rice, Transplacental carcinogenic effects of nickel(II) acetate in the renal cortex, Carcinogenesis 1992, 13, 1351-1357. 
145. G.R. Bunin, K. Noller, P. Rose and E. Smith, Carcinogenesis, in Occupational and Environmental Reproductive Hazards:A Guide for Clinicians, ed. M. Paul, Williams and Wilkins, Baltimore, MD, 1992, pp. 76-88.

146. F.W. Sunderman Jr., Carcinogenicity of metal alloys in orthopedic prostheses: clinical and experimental studies, Fundam. Appl. Toxicol. 1989, 13, 205-216.

147. D.B. McGregor, R.A. Baan, C. Partensky, J.M. Rice and J.D. Wilbourn, Evaluation of the carcinogenic risks to humans associated with surgical implants and other foreign bodies - a report of an IARC Monographs Programme Meeting, Eur. J. Cancer 2000, 36, 307-313.

148. H.-J. Raithel, K.H. Schaller, A. Reith, K.B. Svenes and H. Valentin, Investigations on the quantitative determination of nickel and chromium in human lung tissue. Int. Arch. Occup. Environ. Healh. 1988, 60, 55-66.

149. H.-J. Raithel, K.H. Schaller, T. Kraus and G. Lehnert, Biomonitoring of nickel and chromium in human pulmonary tissue. Int. Arch. Occup. Environ. Health 1993, 65, S197-S200.

150. K. Hughes, M.E. Meek, R. Newhook and P.K.L. Chan, Speciation and health risk assessment of metals: evaluation of effects associated with forms present in the environment, Regul. Toxicol. Pharmacol. 1995, 22, 213-220.

151. W. Goumakos, J.P. Laussac and B. Sarkar, Binding of cadmium(II) and zinc(II) to human and dog serum albumins: an equilibrium dialysis and 113Cd-NMR study. Biochem. Cell Biol. 1991, 69, 809-820.

152. P.J. Sadler and J.H. Viles, ${ }^{1} \mathrm{H}$ and ${ }^{113} \mathrm{Cd}$ NMR investigations of $\mathrm{Cd}^{2+}$ and $\mathrm{Zn}^{2+}$ binding sites on serum albumin: competition with $\mathrm{Ca}^{2+}, \mathrm{Ni}^{2+}, \mathrm{Cu}^{2+}$, and $\mathrm{Zn}^{2+}$, Inorg. Chem. 1996, 35, 4490-4496.

153. W.R. Harris and L.J. Madsen, Equilibrium studies on the binding of cadmium(II) to human serum transferrin. Biochemistry 1988, 27, 284-288.

154. B.J. Scott and A.R. Bradwell, Identification of the serum binding proteins for iron, zinc, cadmium, nickel, and calcium, Clin. Chem. 1983, 29, 629-633.

155. K.T. Suzuki, S. Kawahara, H. Sunaga, E. Kobayashi and N. Shimojo, Discriminative uptake of metals by the liver and its relation to induction of metallothionein by cadmium, copper and zinc, Comp. Biochem. Physiol. C. 1990, 95, 279-284.

156. W. Kadima and D.L. Rabenstein, A quantitative study of the complexation of cadmium in hemolyzed human erythrocytes by 1H NMR spectroscopy, J. Inorg. Biochem. 1990, 40, 141-149.

157. A. Krężel and W. Bal, The coordination chemistry of glutathione, Acta Biochim. Polon. 1999, 46, 567-580.

158. S. Prévéral, L. Gayet, C. Moldes, J. Hoffmann, S. Mounicou, A. Gruet, F. Reynaud, R. Lobinski, J.M. Verbavatz, A. Vavasseur and C. Forestier, A common highly conserved cadmium detoxification mechanism from bacteria to humans: heavy metal tolerance 
conferred by the ATP-binding cassette $(\mathrm{ABC})$ transporter SpHMT1 requires glutathione but not metal-chelating phytochelatin peptides, J. Biol. Chem. 2009, 284, 4936-4943.

159. M.G. Cherian, Chelation of cadmium without increased renal cadmium deposition, Environ. Health Perspect. 1984, 54, 243-248.

160. W. Maret and Y. Li, Coordination dynamics of zinc in proteins, Chem. Rev. in press, doi: $10.1021 / \mathrm{cr} 800556 \mathrm{u}$

161. V. Lalioti, G. Muruais, Y. Tsuchiya, D. Pulido and I.V. Sandoval, Molecular mechanisms of copper homeostasis. Front. Biosci. 2009, 14, 4878-4903.

162. A. Krężel and W. Maret, Dual nanomolar and picomolar Zn(II) binding properties of metallothionein. J. Am. Chem. Soc. 2007, 129, 10911-10921.

163. D.A. Fowle and M.J. Stillman, Comparison of the structures of the metal-thiolate binding site in $\mathrm{Zn}(\mathrm{II})-, \mathrm{Cd}(\mathrm{II})-$, and $\mathrm{Hg}(\mathrm{II})$-metallothioneins using molecular modeling techniques. J. Biomol. Struct. Dyn. 1997, 14, 393-406.

164. G. Henkel and B. Krebs, Metallothioneins: zinc, cadmium, mercury, and copper thiolates and selenolates mimicking protein active site features - structural aspects and biological implications, Chem. Rev. 2004, 104, 801-824.

165. C.D. Klaassen and J. Liu, Induction of metallothionein as an adaptive mechanism affecting the magnitude and progression of toxicological injury, Environ. Health Perspect. 1998, 106 Suppl. 1, 297-300.

166. C.D. Klaassen, J. Liu and B.A. Diwan, Metallothionein protection of cadmium toxicity. Toxicol. Appl. Pharmacol. 2009, 238, 215-220.

167. B.A. Hart, R.J. Potts and R.D. Watkin, Cadmium adaptation in the lung - a double-edged sword? Toxicology 2001, 160, 65-70.

168. M.P. Waalkes and J. Liu, Metallothionein in inorganic carcinogenesis, in A. Sigel, H. Sigel and R.K.O. Sigel, Eds., Met. Ions Life Sci. 2009, vol. 5, pp. 399-412.

169. J. Liu, M.L. Cheng, Q. Yang, K.R. Shan, J. Shen, Y. Zhou, X. Zhang, A.L. Dill and M.P. Waalkes, Blood metallothionein transcript as a biomarker for metal sensitivity: low blood metallothionein transcripts in arsenicosis patients from Guizhou, China. Environ. Health Perspect. 2007, 115, 1101-1106.

170. N. Miura, Individual susceptibility to cadmium toxicity and metallothionein gene polymorphisms: with references to current status of occupational cadmium exposure, Ind. Health 2009, 47, 487-494.

171. C.D. Klaassen, J. Liu, and S. Choudhuri, Metallothionein: an intracellular protein to protect against cadmium toxicity, Annu. Rev. Pharmacol. Toxicol. 1999, 39, 267-294.

172. H.M. Chan, L.-F. Zhu, D. Grant, R.A. Goyer and G.M. Cherian, Nephrotoxicity in rats following liver transplantation from cadmium exposed rats, Toxicol. Appl. Pharmacol. 1993, 123, 89-96. 
173. W.C. Prozialeck, D.R. Wellington and P.C. Lamar, Comparison of the cytotoxic effects of cadmium chloride and cadmium-metallothionein in LLC-PK1 cells, Life Sci. 1993, 53, 337-342.

174. J. Liu, Y. Liu, and C.D. Klaassen, Nephrotoxicity of $\mathrm{CdCl} 2$ and Cd-metallothionein in cultured rat kidney proximal tubules and LLC-PK1 cells. Toxicol. Appl. Pharmacol. 1994, 128, 264-270.

175. J. Liu, Y. Liu, S.S. Habeebu and C.D. Klaassen, Susceptibility of MT-null mice to chronic $\mathrm{CdCl}_{2}$-induced nephrotoxicity indicates that renal injury is not mediated by the CdMT complex. Toxicol. Sci. 1998, 46, 197-203.

176. P. Joseph, Mechanisms of cadmium carcinogenesis, Toxicol. Appl. Pharmacol. 2009, 238, 272-279.

177. W. Bal and K.S. Kasprzak, Induction of oxidative DNA damage by carcinogenic metals, Toxicol. Lett. 2002, 127, 55-62.

178. M.V. Mikhailova, N.A. Littlefield, B.S. Hass, L.A. Poirier and M.W. Chou, Cadmiuminduced 8-hydroxydeoxyguanosine formation, DNA strand breaks and antioxidant enzyme activities in lymphoblastoid cells, Cancer Lett. 1997, 115, 141-148.

179. J. Liu, W. Qu and M.B. Kadiiska, Role of oxidative stress in cadmium toxicity and carcinogenesis, Toxicol. Appl. Pharmacol. 2009, 238, 209-214.

180. G. Bertin and D. Averbeck, Cadmium: cellular effects, modifications of biomolecules, modulation of DNA repair and genotoxic consequences (a review), Biochimie 2006, 88, 1549-1559.

181. J.D. Eneman, R.J. Potts, M. Osier, G.S. Shukla, C.H. Lee, J.F. Chiu and B.A. Hart, Suppressed oxidant-induced apoptosis in cadmium adapted alveolar epithelial cells and its potential involvement in cadmium carcinogenesis, Toxicology 2000, 147, 215-228.

182. M. Kondoh, S. Araragi, K. Sato, M. Higashimoto, M. Takiguchi and M. Sato, Cadmium induces apoptosis partly via caspase-9 activation in HL-60 cells. Toxicology 2002, 170, 111-117.

183. C.M. Shih, W.C. Ko, J.S. Wu, Y.H. Wei, L.F. Wang, E.E. Chang, T.Y. Lo, H.H. Cheng and C.T. Chen, Mediating of caspase-independent apoptosis by cadmium through the mitochondria-ROS pathway in MRC-5 fibroblasts, J. Cell. Biochem. 2004, 91, 384-397.

184. J. Kim and R.P. Sharma, Cadmium-induced apoptosis in murine macrophages is antagonized by antioxidants and caspase inhibitors, J. Toxicol. Environ. Health 2006, 69, 1181-1201.

185. W. Watjen and D. Beyersmann, Cadmium-induced apoptosis in C6 glioma cells: influence of oxidative stress. BioMetals 2004, 17, 65-78.

186. W.E. Achanzar, M.M. Webber and M.P. Waalkes, Altered apoptotic gene expression and acquired apoptotic resistance in cadmium-transformed human prostate epithelial cells, Prostate 2002, 52, 236-244. 
187. J.J. Mukherjee, S.K. Gupta and S. Kumar, Inhibition of benzopyrene diol epoxide induced apoptosis by cadmium(II) is AP-1-independent: role of extracelluler signal related kinase, Chem.-Biol. Interact. 2008, 172, 72-80.

188. W.E. Achanzar, K.B. Achanzar, J.G. Lewis, M.M. Webber and M.P. Waalkes, Cadmium induces c-myc, p53, and c-jun expression in normal human prostate epithelial cells as a prelude to apoptosis, Toxicol. Appl. Pharmacol. 2000, 164, 291-300.

189. J. Liu, C. Corton, D.J. Dix, Y. Liu, M.P. Waalkes and C.D. Klaassen, Genetic background but not metallothionein phenotype dictates sensitivity to cadmium-induced testicular injury in mice, Toxicol. Appl. Pharmacol. 2001, 176, 1-9.

190. P. Joseph, T.K. Muchnok, M.L. Klishis, J.R. Roberts, J.M. Antonini, W.Z. Whong and T. Ong, Cadmium-induced cell transformation and tumorigenesis are associated with transcriptional activation of c-fos, c-jun, and c-myc proto-oncogenes: role of cellular calcium and reactive oxygen species. Toxicol. Sci. 2001, 61, 295-303.

191. P. Joseph, Y.X. Lei, W.Z. Whong and T. Ong, Oncogenic potential of mouse translation elongation factor-1 delta, a novel cadmium-responsive proto-oncogene, J. Biol. Chem. 2002, 277, 6131-6136.

192. P. Joseph, Y.X. Lei and T. Ong, Up-regulation of expression of translation factors-a novel molecular mechanism for cadmium carcinogenesis. Mol. Cell. Biochem. 2004, 255, 93-101.

193. J.H. Hoeijmakers, Genome maintenance mechanisms for preventing cancer, Nature 2001, 411, 366-374.

194. D. Beyersmann and A. Hartwig, Carcinogenic metal compounds: recent insight into molecular and cellular mechanisms, Arch Toxicol. 2008, 82, 493-512.

195. A. Hartwig and T. Schwerdtle, Interactions by carcinogenic metal compounds with DNA repair systems: toxicological implications. Tox. Lett. 2002, 127, 47-54.

196. H. Dally and A. Hartwig, Induction and repair inhibition of oxidative DNA damage by nickel(II) and cadmium(II) in mammalian cells, Carcinogenesis 1997, 18, 1021-1026.

197. T. Fatur, M. Tusek, I. Falnoga, J. Scancar, T.T. Lach and M. Filipic, Cadmium inhibits repair of UV-, methyl methanesulfonate- and N-methyl-N-nitrosothiourea-induced DNA damage in Chinese hamster ovary cells, Mutat. Res. 2003, 529, 109-116.

198. R.D. Watkin, T. Nawrot, R.J. Potts and B.A. Hart, Mechanisms regulating the cadmiummediated suppression of Sp1 transcription factor activity in alveolar epithelial cells, Toxicology 2003, 184, 157-178.

199. A. Hartwig, M. Asmuss, H. Blessing, S. Hoffmann, G. Jahnke, S. Khandelwal, A. Pelzer and A. Burkle, Interference by toxic metal ions with zinc-dependent proteins involved in maintaining genomic stability, Food Chem. Toxicol. 2002, 40, 1179-1184.

200. M. Asmuss, LH.F. Mullenders, A. Elker and A. Hartwig, Differential effects of toxic metal compounds on the activities of Fpg and XPA, two zinc finger proteins involved in DNA repair. Carcinogenesis 2000, 21, 2097-2104. 
201. A. Lutzen, S.E. Liberti and L.J. Rasmussen, Cadmium inhibits human DNA mismatch repair in vivo, Biochem. Biophys. Res. Commun. 2004, 321, 21-25.

202. A.B. Clark and T.A. Kunkel, Cadmium inhibits the functions of eukaryotic MutS complexes, J. Biol. Chem. 2004, 279, 53903-53906.

203. W.C. Prozialeck, J.R. Edwards and J.M. Woods, The vascular endothelium as a target of cadmium toxicity, Life Sci. 2006, 79, 1493-1506.

204. W.C. Prozialeck and J.R. Edwards, Cell Adhesion molecules in chemically-induced renal injury, Pharmacol. Ther. 2007, 114, 74-73

205. B.D. Angst, C. Marcozzi and A.I. Magee, The cadherin superfamily: diversity in form and function, J. Cell Sci. 2001, 114, 629-641.

206. F. Thévenod, N.A. Wolff, U. Bork, W.-K. Lee and M. Abouhamed, Cadmium induces nuclear translocation of $\beta$-catenin and increases expression of $c$-myc and Abcbla in kidney proximal tubule cells, Biometals, 2007, 20, 807-820.

207. H. Chiba, M. Osani, M. Murata, T. Kojima and N. Sawada, Transmembrane proteins of tight junctions, Biochim. Biophys. Acta, 2008, 1778, 558-600.

208. J.M. Woods, M. Leone, K. Klosowska, P.C. Lamar, T.J. Shankovsky and W.C. Prozialeck, Direct antiangiogenic actions of cadmium on human vascular endothelial cells, Toxicol. In Vitro, 2008, 22, 643-651.

209. G. Girolomoni, S. Sebastiani, C. Albanesi and A. Cavani, T-cell subpopulations in the development of atopic and contact allergy, Curr. Opin. Immunol. 2001, 13, 733-737.

210. A. Cavani, Breaking tolerance to nickel, Toxicology 2005, 209, 119-121.

211. R. Kornik and K.A. Zug, Nickel, Dermatitis 2008, 19, 3-8.

212. E. Czarnobilska, K. Obtułowicz, K. Wsołek, J. Piętowska and R. Śpiewak, Mechanisms of nickel allergy, Przeg. Lek. 2007, 64, 502-505.

213. H.-J. Thierse, C. Moulon, Y. Allespach, B. Zimmermann, A. Doetze, S. Kuppig, D. Wild, F. Herberg and H.U. Weltzien, Metal-protein complex-mediated transport and delivery of $\mathrm{Ni}^{2+}$ to TCR/MHC contact sites in nickel-specific human T cell activation, $J$. Immunol. 2004, 172, 1926-1934.

214. P.J. Sadler, A. Tucker and J.H. Viles, Involvement of a lysine residue in the N-terminal $\mathrm{Ni}^{2+}$ and $\mathrm{Cu}^{2+}$ binding site of serum albumins. Comparison with $\mathrm{Co}^{2+}, \mathrm{Cd}^{2+}$ and $\mathrm{Al}^{3+}$, Eur. J. Biochem. 1994, 220, 193-200.

215. W. Bal, J. Christodoulou, P.J. Sadler and A. Tucker, Multi metal binding site of serum albumin, J. Inorg. Biochem. 1998, 70, 33-39.

216. M. Sokołowska, A. Krężel, M. Dyba, Z. Szewczuk and W. Bal, Short peptides are not reliable models of thermodynamic and kinetic properties of the N-terminal metal binding site in serum albumin, Eur. J. Biochem. 2002, 269, 1323-1331. 
217. C. Giwercman, A. Lerbaek, H. Bisgaard and T. Menné, Classification of atopic hand eczema and the filaggrin mutation, Contact Dermatitis 2008, 59, 257-260.

218. J.P. Thyssen, B.C. Carlsen and T. Menné, Nickel sensitization, hand eczema, and lossof-function mutations in the filaggrin gene, Dermatitis 2008, 19, 303-307.

219. N. Novak, H. Baurecht, T. Schäfer, E. Rodriguez, S. Wagenpfeil, N. Klopp, J. Heinrich, H. Behrendt, J. Ring, E. Wichmann, T. Illig and S. Weidinger, Loss-of-function mutations in the filaggrin gene and allergic contact sensitization to nickel, J. Invest. Dermatol. 2008, 128, 1430-1435.

220. Z. Wu, B. Hansmann, U. Meyer-Hoffert, R. Gläser and J.-M. Schröder, Molecular identification and expression analysis of filaggrin-2, a member of the S100 fused-type protein family, PLOS ONE 2009, 4, e5227. doi:10.1371/journal.pone.0005227

221. H.-J. Thierse, K. Gamerdinger, C. Junkes, N. Guerreiro, H.U. Weltzien, T cell receptor (TCR) interaction with haptens: metal ions as non-classical haptens, Toxicology 2005, 209, 101-107.

222. P. Romagnoli, A.M. Labhardt and F. Sinigaglia, Selective interaction of Ni with an MHC-bound peptide, EMBO J. 1991, 10, 1303-1306.

223. L. Lu, J. Vollmer, C. Moulon, H.U. Weltzien, P. Marrack and J. Kappler, Components of the ligand for a $\mathrm{Ni}^{++}$reactive human T cell clone, J. Exp. Med. 2003, 197, 567-574.

224. V. Bordignon, F. Palamara, P. Cordiali-Fei, A. Vento, A. Aiello, M. Picardo, F. Ensoli and A. Cristaudo, Nickel, palladium and rhodium induced IFN-gamma and IL-10 production as assessed by in vitro ELISpot-analysis in contact dermatitis patients, $B M C$ Immunology 2008, 9:19 (http://www.biomedcentral.com/1471-2172/9/19).

225. M. Hindsén, A. Spirén and M. Bruze, Cross-reactivity between nickel and palladium demonstrated by systemic administration of nickel, Contact Dermatitis 2005, 53, 2-8.

226. M. Hirota, M. Suzuki S. Hagino, S. Kagatani, Y. Sasaki, S. Aiba and H. Itagaki, Modification of cell-surface thiols elicits activation of human monocytic cell line THP1: possible involvement in effect of haptens 2,4-dinitrochlorobenzene and nickel sulfate, J. Toxicol. Sci. 2009, 34, 139-150.

227. W. Bal, T. Schwerdtle and A. Hartwig, Mechanism of nickel assault on the zinc finger of DNA repair protein XPA, Chem. Res. Toxicol. 2003, 16, 242-248.

228. S. Artik, C. von Vultée, E. Gleichmann, T. Schwarz and P. Griem, Nickel allergy in mice: enhanced sensitization capacity of nickel at higher oxidation states, J. Immunol. 1999, 163, 1143-1152.

229. S. Artik, K. Haarhuis, X. Wu, J. Begerow and E. Gleichmann, High frequency of anergic T cells with persistent suppressor activity, J. Immunol. 2001, 167, 6794-6803.

230. K.S. Kasprzak, W. Bal, A.A. Karaczyn, The role of chromatin damage in nickel-induced carcinogenesis. Review of recent developments, J. Environ. Monit. 2003, 5, 1-6. 
231. H.-C. Schuppe, A.C. Rönnau, S. von Schmiedeberg, T. Ruzicka, E. Gleichmann and P. Griem, Immunomodulation by heavy metal compounds, Clin. Dermatol. 1998, 16, 149157.

232. W. Bal, J. Lukszo, K. Białkowski and K.S. Kasprzak, Interactions of nickel(II) with histones: interactions of $\mathrm{Ni}(\mathrm{II})$ with $\mathrm{CH}_{3} \mathrm{CO}-\mathrm{Thr}-\mathrm{Glu}$-Ser-His-His-Lys- $\mathrm{NH}_{2}$, a peptide modeling the potential metal binding site in the "C-tail" region of histone $\mathrm{H} 2 \mathrm{~A}$, Chem. Res. Toxicol. 1998, 11, 1014-1023.

233. W. Bal, R. Liang, J. Lukszo, S.-H. Lee, M. Dizdaroglu and K.S. Kasprzak, Ni(II) specifically cleaves the $\mathrm{C}$-terminal tail of the major variant of histone $\mathrm{H} 2 \mathrm{~A}$ and forms an oxidative damage-mediating complex with the cleaved octapeptide, Chem. Res. Toxicol. 2000, 13, 616-624.

234. A.A. Karaczyn, W. Bal, S.L. North, R.M. Bare, V.M. Hoang, R.J. Fisher and K.S. Kasprzak, The octapeptidic end of the C-terminal tail of histone H2A is cleaved-off in cells exposed to carcinogenic Ni(II). Chem. Res. Toxicol. 2003, 16, 1555-1559.

235. A. Krężel, M. Mylonas, E. Kopera and W. Bal, Sequence-specific Ni(II)-dependent peptide bond hydrolysis in a peptide containing threonine and histidine residues, Acta Biochim. Polon. 2006, 53, 721-727.

236. I.M.W. Van Hoogstraten, K.E. Andersen, B.M.E. Von Blomberg, D. Boden, D.P. Bruynzeel, D. Burrows, J.G. Camarasa, A. Dooms-Goossens, G. Kraal, A. Lahti, T. Menné, R.J.G. Rycroft, S. Shaw, D. Todd, K.J.J. Vreeburg, J.D. Wilkinson and R.J. Scheper, Reduced frequency of nickel allergy upon oral nickel contact at an early age. Clin. Exp. Immunol. 1991, 85, 441-445.

237. H. Kerosuo, A. Kullaa, E. Kerosuo, L. Kanerva and A. Hensten Pettersen, Nickel allergy in adolescents in relation to orthodontic treatment and piercing of ears, Am. J. Orthod. Dentofacial Orthop. 1996, 109, 148-154.

238. C.S. Jensen, T. Menné and J.D. Johansen, Systemic contact dermatitis after oral exposure to nickel: a review with a modified meta-analysis, Contact Dermatitis 2006, 54, 79-86.

239. X. Wu, K. Roelofs-Haarhuis, J. Zhang, M. Nowak, L. Layland, E. Jermann and E. Gleichmann, Dose dependence of oral tolerance to nickel, Int. Immunol. 2007, 19, 965975.

240. K. Salnikow and A. Zhitkovich, Genetic and epigenetic mechanisms in metal carcinogenesis and cocarcinogenesis: nickel, arsenic, chromium, Chem. Res Toxicol. 2008, 21, 28-44.

241. J.K. Dunnick, M.R. Elwell, A.E. Radovsky, J.M. Benson, F.F. Hahn, K.J. Nikula, E.B. Barr and C.H. Hobbs, Comparative carcinogenic effects of nickel subsulfide, nickel oxide, or nickel sulfate hexahydrate chronic exposures in the lung, Cancer Res. 1995, $\mathbf{5 5}, 5251-5256$.

242. M. Costa and H.H. Mollenhauer, Carcinogenic activity of particulate nickel compounds is proportional to their cellular uptake, Science 1980, 209, 515-517. 
243. M. Costa, J. Simmons-Hansen, C.W. Bedrossian, J. Bonura and R.M. Caprioli, Phagocytosis, cellular distribution, and carcinogenic activity of particulate nickel compounds in tissue culture, Cancer Res. 1981, 41, 2868-2876.

244. R.M. Evans, P.J. Davies and M. Costa, Video time-lapse microscopy of phagocytosis and intracellular fate of crystalline nickel sulfide particles in cultured mammalian cells, Cancer Res. 1982, 42, 2729-2735.

245. G.G. Fletcher, F.E. Rosetto, J.D. Turnbull and E. Nieboer, Toxicity, uptake, and mutagenicity of particulate and soluble nickel compounds, Environ. Health Perspect. 1994, 102 Suppl. 3, 69-79.

246. A. Longstaff, A.I.T. Walker and R. Jackh, Nickel oxide, potential carcinogenicity - a review and further evidence, in Nickel in the Human Environment, ed. F.W. Sunderman, IARC Scientific Publications, vol. 53, Lyon 1984, pp. 235-244.

247. M. Horie, K. Nishio, K. Fujita, H. Kato, A. Nakamura, S. Kinugasa, S. Endoh, A. Miyauchi, K. Yamamoto, H. Murayama, E. Niki, H. Iwahashi, Y. Yoshida and J. Nakanishi, Ultrafine $\mathrm{NiO}$ particles induce cytotoxicity in vitro by cellular uptake and subsequent Ni(II) release, Chem. Res. Toxicol. 2009, 22, 1415-1426.

248. J. Tallkvist and H. Tjalve, Transport of nickel across monolayers of human intestinal Caco-2 cells, Toxicol. Appl. Pharmacol. 1998, 151, 117-122.

249. M. Knopfel, G. Schulthess, F. Funk and H. Hauser, Characterization of an integral protein of the brush border membrane mediating the transport of divalent metal ions, Biophys. J. 2000, 79, 874-884.

250. E.C. Foulkes and D.M. McMullen, On the mechanism of nickel absorption in the rat jejunum, Toxicology 1986, 38, 35-42.

251. K.S. Kasprzak, Possible role of oxidative damage in metal-induced carcinogenesis, Cancer Invest. 1995, 13, 411-430.

252. L.K. Tkeshelashvili, T.M. Reid, T.J. McBride and L.A. Loeb, Nickel induces a signature mutation for oxygen free radical damage, Cancer Res. 1993, 53, 4172-4174.

253. K.G. Higinbotham, J.M. Rice, B.A. Diwan, K.S. Kasprzak, C.D. Reed and A.O. Perantoni, GGT to GTT transversions in codon 12 of the K-ras oncogene in rat renal sarcomas induced with nickel subsulfide or nickel subsulfide/iron are consistent with oxidative damage to DNA, Cancer Res. 1992, 52, 4747-4751.

254. L.C. Harty, D.G. Guinee Jr., W.D. Travis, W.P. Bennett, J. Jett, T.V. Coby, H. Tazelaar, V. Trastek, P. Pairolero, L.A. Liotta, C.C. Harris and N.E. Caporaso, p53 mutations and occupational exposures in a surgical series of lung cancers, Cancer Epidemiol. Biomark. Prev. 1996, 5, 997-1003.

255. A. Arita and M. Costa, Epigenetics in metal carcinogenesis: nickel, arsenic, chromium and cadmium, Metallomics 2009, 1, 222-228.

256. F. Golebiowski and K.S. Kasprzak, Inhibition of core histones acetylation by carcinogenic nickel(II). Mol. Cell. Biochem. 2005, 279, 133-139. 
257. A.A. Karaczyn, F. Golebiowski and K.S. Kasprzak, Truncation, deamidation, and oxidation of histone H2B in cells cultured with nickel(II), Chem. Res. Toxicol. 2005, 18, 1934-1942.

258. A.A. Karaczyn, F. Golebiowski and K.S. Kasprzak, Ni(II) affects ubiquitination of core histones H2B and H2A, Exp. Cell. Res. 2006, 312, 3252-3259.

259. L. Broday, W. Peng, M.H. Kuo, K. Salnikow, M. Zoroddu and M. Costa, Nickel compounds are novel inhibitors of histone H4 acetylation, Cancer Res. 2000, 60, 238241.

260. H. Chen, Q. Ke, T. Kluz, Y. Yan and M. Costa, M. Nickel ions increase histone H3 lysine 9 dimethylation and induce transgene silencing, Mol. Cell. Biol. 2006, 26, 37283737.

261. Q. Ke, T. Davidson, H. Chen, T. Kluz and M. Costa, Alterations of histone modifications and transgene silencing by nickel chloride, Carcinogenesis 2006, 27, 1481-1488.

262. A.A. Karaczyn, R.Y.S. Cheng, G.S. Buzard, J. Hartley, D. Esposito and K.S. Kasprzak, Truncation of histone H2A's C-terminal tail, as is typical for Ni(II)-assisted specific peptide bond hydrolysis, has gene expression altering effects, Ann. Clin. Lab. Sci. 2009, 39, 251-262.

263. W. Li, Y. Zhao and I.N. Chou, Alterations in cytoskeletal protein sulfhydryls and cellular glutathione in cultured cells exposed to cadmium and nickel ions. Toxicology 1993, 77, 65-79.

264. S. Lynn, F.H. Yew, J.-W. Hwang, M.-J. Tseng and K.Y. Jan, Glutathione can rescue the inhibitory effects of nickel on DNA ligation and repair synthesis. Carcinogenesis 1994, 15, 2811-2816.

265. W. Li, Y. Zhao and I.N. Chou, $\mathrm{Mg}^{2+}$ antagonism on $\mathrm{Ni}^{2+}$-induced changes in microtubule assembly and cellular thiol homeostasis. Toxicol. Appl. Pharmacol. 1996, 136, 101-111.

266. K. Salnikow, M. Gao, V. Voitkun, X. Huang and M. Costa, Altered oxidative stress responses in nickel-resistant mammalian cells, Cancer Res. 1994, 54, 6407-6412.

267. K. Salnikow and K.S. Kasprzak, Ascorbate depletion: a critical step in nickel carcinogenesis, Environ. Health Perspect. 2005, 113, 577-584.

268. K. Salnikow, T. Davidson, Q. Zhang, L.C. Chen, W. Su and M. Costa, The involvement of hypoxia-inducible transcription factor-1-dependent pathway in nickel carcinogenesis, Cancer Res. 2003, 63, 3524-3530.

269. M. Kaczmarek, R.E. Cachau, I.A. Topol, K.S. Kasprzak, A. Ghio and K. Salnikow, Metal ions-stimulated iron oxidation in hydroxylases facilitates stabilization of HIF-1 alpha protein, Toxicol Sci. 2009, 107, 394-403.

270. R.E. Rodriguez, M. Misra, B.A. Diwan, C.W. Riggs and K.S. Kasprzak, Relative susceptibilities of $\mathrm{C} 57 \mathrm{BL} / 6,(\mathrm{C} 57 \mathrm{BL} / 6 \times \mathrm{C} 3 \mathrm{H} / \mathrm{He}) \mathrm{F} 1$, and $\mathrm{C} 3 \mathrm{H} / \mathrm{He}$ mice to acute toxicity and carcinogenicity of nickel subsulfide, Toxicology 1996, 107, 131-140. 
271. A. Hartwig, L.H.F. Mullenders, R. Schlepegrell, U. Kasten and D. Beyersmann, Nickel(II) interferes with the incision step in nucleotide excision repair in mammalian cells. Cancer Res. 1994, 54, 4045-4051.

272. F. Iwitzki, R. Schlepegrell, U. Eichhorn, B. Kaina, D. Beyersmann and A. Hartwig, Nickel(II) inhibits the repair of O6-methylguanine in mammalian cells, Arch. Toxicol. 1998, 72, 681-689.

273. T. Schwerdtle, A. Seidel and A. Hartwig, Effect of soluble and particulate nickel compounds on the formation and repair of stable benzo[a]pyrene DNA adducts in human lung cells, Carcinogenesis 2002, 23, 47-53.

274. M. Asmuss, L.H.F. Mullenders, A. Elker and A. Hartwig, Differential effects of toxic metal compounds on the activities of Fpg and XPA, two zinc finger proteins involved in DNA repair, Carcinogenesis 2000, 21, 2097-2104.

275. W. Bal, M. Jeżowska-Bojczuk, J. Lukszo and K.S. Kasprzak, Interactions of nickel(II) with histones. Stability and solution structure of complexes with $\mathrm{CH}_{3} \mathrm{CO}-\mathrm{Cys}$-Ala-IleHis- $\mathrm{NH}_{2}$, a putative metal binding sequence of histone H3, Chem. Res. Toxicol. 1995, 8 , 683-692.

276. W. Bal, J. Lukszo and K.S. Kasprzak, Interactions of nickel(II) with histones.: Enhancement of 2 -deoxyguanosine oxidation by $\mathrm{Ni}$ (II) complexes with $\mathrm{CH}_{3} \mathrm{CO}-\mathrm{Cys}-$ Ala-Ile-His- $\mathrm{NH}_{2}$, a putative metal binding sequence of histone H3, Chem. Res. Toxicol. 1996, 9, 435-440.

277. W. Bal, V. Karantza, E.N. Moudrianakis, and K.S. Kasprzak, Interactions of nickel(II) with the histone core tetramer in vitro, Arch. Biochem. Biophys. 1999, 364, 161-166.

278. A. Krężel, W. Szczepanik, M. Sokołowska, M. Jeżowska-Bojczuk, W. Bal, Correlations between complexation modes and redox activities of Ni(II)-GSH complexes, Chem. Res. Toxicol. 2003, 16, 855-864.

279. K.S. Kasprzak, J.M. Ward, L.A. Poirier, D.A. Reichardt, A.C. Denn III and C.W. Reynolds, Nickel-magnesium interactions in carcinogenesis: dose-effects and involvement natural killer cells, Carcinogenesis 1987, 8, 1005-1011.

280. W. Maret, Cellular zinc and redox states converge in the metallothionein/thionein pair, $J$. Nutr. 2003, 133, 1460S-1462S.

281. J.P. Mackay and M. Crossley, Zinc fingers are sticking together, Trends Biochem. Sci. 1998, 23, 1-4.

282. J.H. Laity, B.M. Lee and P.E. Wright, Zinc finger proteins: new insights into structural and functional diversity, Curr. Opin. Struct. Biol. 2001, 11, 39-46.

283. W. Maret, Zinc and sulfur: a critical biological partnership, Biochemistry 2004, 43, 33013309.

284. A. Witkiewicz-Kucharczyk and W. Bal, Damage of zinc fingers in DNA repair proteins, a novel molecular mechanism in carcinogenesis, Toxicol. Lett. 2006, 162, 29-42. 
285. K.-D. Kröncke and L.-O. Klotz, Zinc fingers as biologic redox switches? Antioxid. Redox Signal. 2009, 11, 1015-1027.

286. A. Hartwig, Zinc finger proteins as potential targets for toxic metal ions: differential effects on structure and function, Antioxid. Redox Signal. 2001, 3, 625-634.

287. B.A. Krizek and J.M. Berg, Complexes of zinc finger peptides with $\mathrm{Ni}^{2+}$ and $\mathrm{Fe}^{2+}$, Inorg. Chem. 1992, 31, 2984-2986.

288. M.C. Posewitz and D.E. Wilcox, Properties of the Sp1 zinc finger 3 peptide: coordination chemistry, redox reactions, and metal binding competition with metallothionein, Chem. Res. Toxicol. 1995, 8, 1020-1028.

289. G.S. Makowski and F.W. Sunderman, Jr., The interactions of zinc, nickel and cadmium with Xenopus transcription factor IIIA, assessed by equilibrium dialysis, J. Inorg. Biochem. 1992, 48, 107-119.

290. G.S. Makowski, S.-M. Lin, S.M. Brennan, H.M. Smilowitz, S.M. Hopfer and F.W. Sunderman, Jr., Detection of two Zn-finger proteins of Xenopus laevis, TFIIIA, and p43, by probing western blots of ovary cytosol with ${ }^{65} \mathrm{Zn}^{2+},{ }^{63} \mathrm{Ni}^{2+}$, or ${ }^{109} \mathrm{Cd}^{2+}$, Biol. Trace Elem. Res. 1991, 29, 93-109.

291 B.A. Krizek, D.L. Merkle and J.M. Berg, Ligand variation and metal ion binding specificity in zinc finger peptides, Inorg. Chem. 1993, 32, 937-940.

292. D. Krepkiy, F.H. Försterling and D.H. Petering, Interaction of $\mathrm{Cd}^{2+}$ with $\mathrm{Zn}$ finger of transcription factor IIIA: structures and binding to cognate DNA, Chem. Res. Toxicol. 2004, 17, 863-870.

293. M. Huang, D. Krepkiy, W. Hu and D.H. Petering, Zn-, Cd-, and Pb-transcription factor IIIA: properties, DNA binding and comparison with TFIIIA-finger 3 metal complexes, J. Inorg. Biochem. 2004, 98, 775-785.

294. E. Kopera, T. Schwerdtle, A. Hartwig and W. Bal, Co(II) and Cd(II) substitute for Zn(II) in the zinc finger derived from the DNA repair protein XPA, demonstrating a variety of potential mechanisms of toxicity, Chem. Res. Toxicol. 2004, 17, 1452-1458.

295. G.W. Buchko, N.J. Hess and M.A. Kennedy, Human nucleotide excision repair protein XPA: summary of EXAFS studies on the $\mathrm{Zn}(\mathrm{II}), \mathrm{Co}(\mathrm{II})$ and $\mathrm{Cd}(\mathrm{II})$ associated minimal DNA-binding domain, Protein Pept. Lett. 2000, 7, 49-56.

296. G.W. Buchko, N.J. Hess and M.A. Kennedy, Cadmium mutagenicity and human nucleotide excision repair protein XPA: CD, EXAFS and 1H/15N-NMR spectroscopic studies on the zinc(II)- and cadmium(II)-associated minimal DNA-binding domain (M98-F219), Carcinogenesis 2000, 21, 1051-1057.

297. P.F. Predki P. F. and B. Sarkar, Effect of replacement of ,zinc finger” zinc on estrogen receptor DNA interactions, J. Biol. Chem., 1992, 267, 5842-5846.

298. L. Nagy and J.W.R. Schwabe, Mechanism of the nuclear receptor molecular switch, Trends Biochem. Sci., 2004, 29, 317-324. 
299. M.B. Martin, R. Reiter, T. Pham, Y.R. Avellanet, J. Camara, M. Lahm., E. Pentecost, K. Pratap, B.A. Gilmore, S. Diverkar, R.S. Dagata, J.L. Bull and A. Stoica. Estrogen-like activity of metals in Mcf-7 breast cancer cells. Endocrinology, 2003, 144, 2425-2436.

300. A. Stoica, B.S. Katzenellenbogen, and M.B. Martin Activation of estrogen receptor $\alpha$ by the heavy metal cadmium. Mol. Endocrinol. 2000, 14, 545-553.

301. V.J. Nesatyy, B.V. Rutishauser, R.I. Eggen and M.J. Suter, Identification of the estrogen receptor Cd-binding sites by chemical modification, Analyst 2005, 130, 1087-1097. 